\title{
Strain rate effects in deep marine clays from the Gulf of Guinea
}

\author{
Seda Sendir Torisu ${ }^{a}$, Jean-Michel Pereira ${ }^{a}$, Vincenzo De Gennaro ${ }^{b}$, Pierre Delage $^{a}$, Alain Puech ${ }^{c}$ \\ a Université Paris-Est, Laboratoire Navier (CNRS-IFSTTAR-ENPC), CERMES, \\ Ecole des Ponts ParisTech, 6-8 av. Bl. Pascal, F-77455 Marne-la-Vallée, France. \\ b PhD, MSc, CEng, Ecole des Ponts ParisTech, Marne-la-Vallée, France \\ at present: Senior Geomechanics Engineer at Schlumberger, Pau, France. \\ ${ }^{\mathrm{c}}$ FUGRO France, 39 rue des Peupliers, 92752 Nanterre Cedex, France.
}

\begin{abstract}
Current developments in deepwater offshore oil production in the Gulf of Guinea (GoG) make it necessary to characterise better the mechanical behaviour of the GoG deepwater sediments. This paper examines some aspects of the strain rate dependent behaviour of intact and reconstituted GoG clay specimens. Results from isotropic compression and undrained shearing laboratory tests with changing rates of stress or strain are presented. They show that the soil generally follows an Isotach behaviour, with clear strain rate dependency of the stress-strain behaviour and pore pressure response in the undrained shear tests. The effects of structure and its degradation on the time-dependent response of the sediments seem to confirm general trends observed in other structured clays.
\end{abstract}

\footnotetext{
RESUME : L'exploitation actuelle des champs pétrolifères en eaux profondes dans le Golfe de Guinée (GdG) rend nécessaire une meilleure caractérisation du comportement mécanique des sédiments marins profonds du GdG. Cet article traite de quelques aspects de la dépendance vis-à-vis du taux de déformation du comportement d'échantillons intacts et reconstitués d'argiles du GdG. Les résultats d'essais de compression isotrope et triaxiaux non-drainés réalisés à des taux de déformation variables sont présentés. Ils montrent que le sol se caractérise globalement par un comportement Isotach, avec une dépendance claire vis-à-vis du taux de déformation de la réponse en contraintes-déformations ainsi que de la réponse en pression interstitielle dans le cas
} 
des essais de cisaillement non-drainé. Les effets de la structure et de sa dégradation sur la réponse dépendant du taux de déformation de ces sédiments semblent confirmer les tendances générales observées dans le cas d'autres argiles structurées.

\section{LIST OF NOTATIONS AND ACRONYMS}

$B$

CAUc

CAUe

$E$

$\varepsilon_{\mathrm{a}}$

$\varepsilon_{\mathrm{VOL}}$

GoG

$I_{p}$

OCR

p

$I_{p}$

$q$

$u$

$v$

$w_{L}$

$w_{p}$

$\varepsilon_{\mathrm{a}}$

$\varepsilon_{\mathrm{VOL}}$

SHANSEP

$\sigma_{\mathrm{a}}^{\prime}$
Skempton coefficient

Anisotropically Consolidated Undrained triaxial compression

Anisotropically Consolidated Undrained triaxial extension

void ratio

axial strain

volumetric strain

Gulf of Guinea

plasticity index

overconsolidation ratio, $=\sigma_{p}{ }^{1} / \sigma_{v}{ }^{\prime}$

current mean effective stress, $=\frac{1}{3}\left(\sigma_{a}{ }^{\prime}+2 \sigma_{r}{ }^{\prime}\right)$

plasticity index

deviator stress, $=\sigma_{a}{ }^{\prime}-\sigma_{r}{ }^{\prime}$

pore water pressure

specific volume, $=1+e$

liquid limit

plastic limit

axial strain

volumetric strain

Stress History And Normalized Soil Engineering Properties axial effective stress (principal) 


$\begin{array}{ll}\sigma_{\mathrm{p}}{ }^{\prime} & \text { vertical preconsolidation pressure } \\ \sigma_{\mathrm{r}}^{\prime} & \text { radial effective stress (principal) } \\ \sigma_{\mathrm{v}}^{\prime} & \text { vertical effective stress } \\ \sigma_{\mathrm{vy}}{ }^{\prime} & \text { vertical effective yield stress } \\ \sigma_{\mathrm{vo}}, & \text { in situ vertical effective stress }\end{array}$

\section{INTRODUCTION}

Increasing energy demand has made the exploitation of deep-water offshore oil fields a strategic goal for oil producing companies. The installation of offshore geotechnical structures at great depth requires a better knowledge of the mechanical behaviour of the sediments on which they are founded. Deep-sea sediments are often characterised as sensitive with a susceptibility to time effects. These two features play a key role in the prediction of the short- and long-term stability and performance of deep offshore geotechnical structures.

This paper focuses on the strain rate dependent behaviour of deep marine soft sediments from the Gulf of Guinea (GoG) in Western Africa. It reports collaborative research designed to provide a database of the geotechnical properties of the GoG marine sediments. The experimental programme included laboratory tests on both intact and reconstituted GoG marine sediment specimens as well as specimens subjected to the SHANSEP reconsolidation method (Ladd and Foott, 1974).

\section{ON THE STRAIN RATE DEPENDENT BEHAVIOUR OF CLAYS}

Before entering into the details of the present study, an overview is given of the trends in behaviour that may be expected in clays when subjected to strain rate changes, with a brief summary of the effects of strain rate changes on the overall stress-strain curves and on the shear 
strengths. The role that soil structure plays in this strain rate dependency is also discussed. This overview provides the framework within which the experiments on GoG clays will be discussed.

The strain rate dependent behaviour of different types of soils has been investigated by various authors including Casagrande and Wilson (1950); Alberro and Santoyo (1973); Vaid and Campanella (1977); Graham et al. (1983); Lefebvre and LeBoeuf (1987); Leroueil et al. (1996); Zhu and Yin (2000); Tatsuoka et al. (2002); Sorensen et al. (2007); Jung et al. (2009); Colliat et al. (2010) ; Rattley et al. (2010); Sorensen et al. (2010). Richardson and Whitman (1963) were the first to propose step changes in the strain rates applied to a specimen during testing as an investigative tool. A general conclusion drawn by several authors is that the undrained shear strength increases with strain rate and that the overall stress-strain curves are sensitive to the loading or strain rate.

For example, studies on Mexico City clay, a high plasticity clay $\left(w_{L}=140-380 \% ; w_{p}=55-112 \%\right)$ with high void ratios $(e=3-9)$ reported by Alberro and Santoyo (1973) indicated that the peak effective friction angle increased by $2-3^{0}$ for each log cycle of strain rate. They also showed that the strain at the peak state was strain rate independent. Diaz-Rodriguez et al. (2009) drew the same conclusions and showed that shear strain localization tended to develop more with increased strain rate. Zhu and Yin (2000) performed 24 consolidated-undrained triaxial tests under both compression and extension on saturated remoulded specimens of Hong-Kong marine clay with different over consolidation ratios (OCRs) and shear rates. They showed that the undrained shear strength increased with increased strain rates independently of the OCR value. Jung et al. (2009) reported that the undrained shear strength of seabed Holocene clay at the Kobe airport site was increased both by the imposed strain rate and the consolidation time prior to shearing. 
A general framework has been described for the effects of strain rate changes on the stress-strain curves by Tatsuoka and co-workers (see e.g. Tatsuoka, 2007). They pointed out that different types of viscous behaviour can be observed. One mode was Isotach behaviour, where stress-strain curves are uniquely related to strain rates so that the response of a specimen submitted to changing strain rate will jump at each rate change to follow the curve corresponding to the new applied rate, with a stiffer and strengthened response at larger strain rates. In another mode of behaviour called TESRA (Temporary Effect of Strain Rate and Acceleration), the jump that takes place when rates are changed decays with increasing strain and the soil response reverts to a unique curve. An intermediate mode called "Isotach-and-TESRA-Combined" (in short Combined) corresponds to a temporary jump returning to a different strain rate dependent curve. As for the TESRA behaviour, the effects of changing strain rate tend to decay after some strain but do not totally disappear.

Following Richardson and Whitman (1963), Graham et al. (1983) found that intact specimens of lightly overconsolidated Belfast and Winnipeg clays exhibit Isotach behaviour during triaxial testing. This behaviour was also observed by Jung et al. (2009) for the natural clay from the Kobe airport site. Tatsuoka et al. (2002) carried out triaxial tests with step-changed strain rates on soils that exhibited a range of modes and then simulated their behaviour with time-dependent models. Although the Isotach behaviour was observed at small strains in the pre-peak regime, Combined behaviour was observed at larger strains and became obvious in the post-peak regime. The role played by the structure of clays on the strain rate dependency of their behaviour has also been investigated on both undisturbed and reconstituted clays under 1D and isotropic compression tests by Leroueil et al. (1996) and Acosta-Martinez et al. (2003). Both studies indicated Isotach behaviour. The same was observed in triaxial conditions by Komoto et al. (2003) and Sorensen et al. (2007). Komoto et al. (2003) tested undisturbed and reconstituted 
Pleistocene clay under drained triaxial conditions. They observed the same mode (Isotach) for both states, although a sharper sensitivity to strain rate changes was reported for their reconstituted specimens. In contrast, Sorensen et al. (2007) tested undisturbed and reconstituted specimens of London clay -a stiff and heavily over-consolidated Eocene fissured clay- by changing the strain rates stepwise. They observed Isotach behaviour for the undisturbed over-consolidated specimens both pre- and post-peak. However, the Isotach behaviour observed at low stresses for reconstituted overconsolidated specimens changed towards the Combined behaviour at higher stresses, highlighting the effect of the structure of the specimen on the rate-dependency of London Clay.

As presented in the above studies, strain rate effects play a major role in the behaviour of clays. In the present study, the influence of the strain rate was investigated on specimens reconsolidated in two different ways - either to the soil's in-situ stress state or using the SHANSEP method which brings the soil to stress states significantly higher than the in-situ conditions. The specimens were then sheared with step-wise changes in strain rate. Reconstituted specimens were also reconsolidated to the in-situ stress conditions and sheared in the same manner for comparison. Additionally, isotropic compression tests were performed on intact and reconstituted specimens by changing the rate of change of effective confining stress in a stepwise manner. The results are reviewed within the general framework outlined above.

\section{MATERIALS AND TESTING PROCEDURES}

High quality piston samples of GoG clays (Puech et al., 2005) were retrieved at water depths of 600 to $1,300 \mathrm{~m}$ from different GoG clay sites at locations up to $8 \mathrm{~m}$ below the seabed. GoG clays have high void ratios $(e=3-5)$, high water contents (typically between $150 \%-250 \%$ at seabed 
and between $100 \%-150 \%$ at $8 \mathrm{~m}$ depth), high plasticity indexes (in general $I_{p}=150$ and $w_{L}=200 \%$ at seabed and $I_{p}=80$ and $w_{L}=120 \%$ at $8 \mathrm{~m}$ depth $)$, a low shear strength $\left(c_{u}=5-30\right.$ $\mathrm{kPa}$ over 2om depth), and sensitivities ranging between 2 and 5, practically independent of depth. GoG clays have a calcium carbonate content of about 5 to $10 \%$. The clay fraction (around 50 to $80 \%<2 \mu \mathrm{m}$ ) is mostly composed of kaolinite (about $50 \%$ of the clay fraction) and smectite (typically 15 to $25 \%$ of the clay fraction), which are responsible for the very high plasticity of the GoG sediments, along with a small percentage of illite (Thomas et al., 2005; Colliat et al., 2010).

The samples from sites $\mathrm{Z}$ and $\mathrm{M}$ were retrieved with a STACOR giant piston corer (Borel et al., 2005). Intact specimens were trimmed from core samples to the desired dimensions $(38 \mathrm{~mm}$ diameter $\mathrm{x} 76 \mathrm{~mm}$ height). Reconstituted specimens were prepared by thoroughly mixing the soil with tap water at a water content equal to its liquid limit. Distilled water was not used since it can alter the structure of the clay (Filz et al., 2001). Vertical drains made up of thin bands of wetted filter paper were used in all tests, on intact and reconstituted specimens. By reducing the drainage path, these drains significantly improved the drainage. During the preparation of reconstituted specimens, the drains were placed vertically along the inner wall of the mould before pouring the slurry layer by layer. The slurry was stirred after placing each layer so as to avoid trapping air bubbles. After removing the mould, the reconstituted specimens (with their drains) were quickly placed in the triaxial cell and the membrane placed. Tap water was then circulated from the bottom to the top of the specimen.

\section{Testing Apparatus}

A Bishop-Wesley triaxial cell (Bishop and Wesley, 1975) suitable for specimens of $38 \mathrm{~mm}$ diameter was used. The axial deformation was monitored externally by using an LVDT ( $\pm 4 \mu \mathrm{m}$ precision) in contact with the piston. The LVDT was previously calibrated using a moving frame 
and a digital calliper. Pressure/volume controllers (PVC, manufactured by GDS Instruments) were used to control the cell pressure, the back pressure and to impose the axial stress (by controlling either the stress or the strain rate). Volume changes were monitored by using the back pressure PVC. According to the manufacturer, the PVC devices are reported to offer an accuracy of $0.25 \%$ of the measured volume value and of $0.15 \%$ of the full stress range giving an accuracy of $3 \mathrm{kPa}$.

\section{Testing Programme}

The testing programme, presented in Table 1, lists the three types of tests performed on specimens from sites $\mathrm{Z}$ and $\mathrm{M}$ taken at various depths:

- Isotropic compression tests with changing stress rates $(0.5,1$ and $5 \mathrm{kPa} / \mathrm{h})$ were carried out mainly on intact specimens from sites Z and M. Additional tests Z4 and M2 (at a constant rate of $5 \mathrm{kPa} / \mathrm{h}$ ) and test $\mathrm{Z} 7$ (at $0.5,1$ and $5 \mathrm{kPa} / \mathrm{h}$ ) were performed on reconstituted specimens. These stress rates were chosen to ensure drained conditions;

- Undrained shearing tests at various axial strain rates (0.05, 0.5 and $5 \% / \mathrm{h})$ carried out on intact specimens from sites $\mathrm{Z}$ and $\mathrm{M}$ consolidated to in-situ stress conditions, and test M6 on a reconstituted specimen;

- Undrained shearing triaxial tests in compression and extension on initially intact specimens consolidated to SHANSEP stress conditions at various axial strain rates (0.05, 0.5 and $5 \% / \mathrm{h})$.

The specimens were saturated under isotropic effective stresses of 10 to $15 \mathrm{kPa}$. These values were chosen to be sufficiently high to avoid any damage of the specimen during the saturation due to swelling and sufficiently low to remain below the in-situ mean stresses of the specimens. In the isotropic tests, the specimens were saturated by increasing simultaneously the cell 
pressure and the back pressure while maintaining a constant mean effective stress $p^{\prime}{ }_{\max }=10 \mathrm{kPa}$. In other tests, the $p_{\max }^{\prime}$ value was set to be equal to half the in-situ deviator stress $q_{o}$. In all tests, values of the Skempton coefficient $B$ higher than $95 \%$ were achieved. Details of the stress conditions during the saturation process for each test are given in Table 1.

In-situ stress conditions were achieved by increasing first the cell pressure $\sigma_{3}$ and secondly the axial stress $\sigma_{1}$ to the in-situ values. SHANSEP stress conditions were achieved by using the same procedure, followed by a drained $\mathrm{K}_{\mathrm{o}}$ loading up either 3 or 5 times the in-situ stress to achieve normal consolidation. In contrast to a conventional SHANSEP procedure, the specimens were not allowed to swell after consolidation, and no attempt was made to simulate the apparent overconsolidation seen in the intact specimens. $\mathrm{K}_{\mathrm{o}}$ values between 0.44 and 0.48 were adopted from data obtained previously by FUGRO for these clays. The specimens consolidated to their in-situ stress condition were submitted to undrained triaxial compression whereas the SHANSEP specimens were submitted to both undrained compression and extension. Prior to shearing, the specimens were subjected to a creep stage, which was stopped when the excess pore pressure became negligible (less than $1 \mathrm{kPa}$ ) and the volumetric strain rate tended to stabilize (below $0.1 \% / \mathrm{h}$ ). The creep period durations (between 4 and $33 \mathrm{~h}$ ) and induced volumetric strains are reported in Table 1.

\section{RESULTS AND DISCUSSION}

Stress rate effects in drained isotropic compression for intact specimens

The responses shown by intact specimens from sites $\mathrm{Z}$ and $\mathrm{M}$ during drained isotropic compression at various stress rates $(0.5,1$ and $5 \mathrm{kPa} / \mathrm{h})$ are presented in Figure $1 \mathrm{a}$ and $\mathrm{b}$ with the data obtained from test $Z_{3}$ (depth $19.32 \mathrm{~m}$ ) and $\mathrm{M}_{3}$ (depth $11.35 \mathrm{~m}$ ) respectively. The excess pore 
water pressures, measured at one isolated end of each specimen, were checked to be negligible with respect to the mean effective stress. Parallel compression tests were run at a constant stress rate of $5 \mathrm{kPa} / \mathrm{h}$ to provide a reference curve that is typical of these deep soft marine clays, with log-linear curves post-yield and yield stresses equal to 62 and $50 \mathrm{kPa}$ for specimens $\mathrm{Z}_{4}$ and $\mathrm{M}_{3}$, respectively (at $5 \mathrm{kPa} / \mathrm{h}$ ).

In both cases, the curves from the tests run at variable rates show sections that vary systematically with stress rate, with the curves for the faster tests stacking above those run at lower rates. The changing stress rate curves are consistent with the constant stress rate $(5 \mathrm{kPa} / \mathrm{h})$ trace. Imposing a constant stress rate on a non-linear material leads to variable strain rates and the constant stress rate material properties must therefore track across a family of constant strain rate curves. However, the instantaneous strain rates increase progressively as the stress rates increase. Checks showed that these changes led to volumetric strain rates that varied by a factor of 3 for tests at constant stress rate (M2 and $\mathrm{Z}_{4}$ ) and 10 for any sub-stage of the step changed stress rate tests ( $\mathrm{M}_{3}$ and $\left.\mathrm{Z}_{3}\right)$. Despite these changing strain rates, the behaviour appears similar to the Isotach pattern. It is relatively easy to extrapolate parallel compression curves corresponding to each stress rate (in dotted lines) in the plastic regime. The yield stress increased systematically with stress rate, as noted by other workers. When increasing or decreasing the stress rate, the trace moves towards a pseudo-parallel compression curve defined by the new imposed stress rate. Slight stress-relaxation is observed when the load rate is reduced, which is due to time lag effects in the PVC used to impose stresses. These episodes are equivalent to small stress-relaxation tests, as previously observed by Graham et al. (1983) in controlled strain rate oedometer tests. 
Strain rate effects in undrained shear tests, specimens consolidated to the in-situ stress state Figure 2 presents the results of test M1 carried out on an intact specimen (depth $13.72 \mathrm{~m}$ ) initially consolidated to its in-situ stress, in terms of deviator stress (a) and pore pressure (b) plotted against axial strain. The strain rates are expressed with respect to the reference value of $0.05 \% / \mathrm{h}$ (corresponding to number 1), so the numbers 10 and 100 correspond to rates of 0.5 and $5 \% / \mathrm{h}$ respectively. To aid comparison, Figure $2 \mathrm{a}$ also presents the results of a constant rate test carried out by FUGRO on a specimen from the same core at a depth of $15.86 \mathrm{~m}$ at a rate of $0.83 \% / \mathrm{h}$ corresponding to 16.6 times the reference rate.

As commonly described in the literature, it can be observed that the increase in strain rate imposed at low strains before peak (2\%) significantly increases the stiffness and strength of the clay. The pre-peak stress-strain curves show a systematic ordering with the strain rate ratio, while the strain at the peak shear strength appears to be independent of strain rate as tests M1 and STB2 (100 and 16.6) both reach peak at $2 \%$ strain. The successive changes in strain rate imposed post-peak also stack in order of strain rate and show nearly parallel curves. This response is representative of an Isotach behaviour. It is worth noting that the effective stress is sensitive to strain rate so that the strain rate dependency observed in Figure 2a is not simply due to the acceleration of axial strain. This can be checked by inspecting the relationship between $q / p$, and axial strain (Komoto et al., 2003), which also shows an Isotach response.

The changes in strain rate also affect the excess pore pressures (Figure 2b). Shearing at a strain rate ratio of 10 leads to an increase in pore pressure (of up to $10 \mathrm{kPa}$ ) with a clear jump on acceleration from 10 to 100 pre-peak. The trend curves that follow are well ordered with respect to the strain rate. The additional pore pressure generated at peak is equal to $13.6 \mathrm{kPa}$. Reducing the strain rate by $1 / 100$ post-peak leads to $q$ dropping from 65 to $51 \mathrm{kPa}$ at $2 \%$ while the pore pressure falls by $3.6 \mathrm{kPa}$. This response confirms that the higher the strain rate, the higher the 
excess pore pressure.

Finally, the effective stress paths followed in tests M1 and STB2 are presented in a $q-p$ ' diagram (Figure 2c). Again, there is satisfactory correspondence between the test traces. The pre-peak effective stress paths are nearly vertical, but viscous effects are reflected in the dependency of the pore water generation on strain rate changes. The post-peak effective stress paths remain within the same group and generally show reducing effective friction angles after reaching around $46^{\circ}$, a high value that has been already reported for these clays by Colliat et al. (2010).

The results from test $\mathrm{Z} 2$ (on an intact specimen from a depth of $16.72 \mathrm{~m}$ from site $\mathrm{Z}$ and the same initial in-situ conditions as in test M1) are presented in Figure $3 \mathrm{a}\left(q-\varepsilon_{1}\right)$, Figure $3 \mathrm{~b}\left(\Delta \mathrm{u}-\varepsilon_{1}\right)$ and Figure $3 \mathrm{c}$ (effective stress path). The undrained stress-strain curves for tests at a strain rate ratio of 16.6 carried out on specimens from the same piston cores at depths of $16.07 \mathrm{~m}$ and $21.87 \mathrm{~m}$ are also presented. The observations made for test M1 again to the deviator stress and pore pressure dependency on strain rate before and after peak. The $q-\varepsilon_{1}$ curve of test Z2 (16.72m) falls above that at $16.07 \mathrm{~m}$ and below that at $21.87 \mathrm{~m}$, maintaining the hierarchy of effective pressures and a predominantly Isotach response is observed. The differences of excess pore pressure resemble those for M1, but show a smaller sensitivity to strain rate. The post-peak excess pore pressures stabilise at between 13 and $15 \mathrm{kPa}$. The shapes of the effective stress paths are also similar, with a nearly vertical pre-peak path for the intact clay, and viscous effects applying to the excess pore pressure behaviour. The peak effective friction angle is again close to $46^{\circ}$, with lower values at larger strains. Note however that a shear plane developed at peak in test $Z 2$ so that the post-peak behaviour was no longer representative of a continuum.

The role played by the structure of the intact clay can be observed in Figure 4 where the data for test M1 (15.72 m) on an intact specimen are compared with those obtained for a reconstituted 
specimen (test M6, 16.72 m) consolidated at the same in-situ effective stresses. The deviator stress (Figure 4a) indicates a weaker response in the reconstituted specimen with $q_{\max }$ values located between 35 and $40 \mathrm{kPa}$ compared to $55-65 \mathrm{kPa}$ in the intact state. The reconstituted specimen also does not present the clearly defined peak seen for the intact clays, and the maximum shear stress is attained at a higher axial strain (between 3 and $4 \%$ ) in the reconstituted specimen. Nevertheless, the effects of the changes in strain rate are generally similar, with stronger responses developing as strain rates increase. The shape of the stress-strain sections applying over fixed strain rates are however different. Over the two sections corresponding to $0<\varepsilon_{1}<1 \%$ and $1<\varepsilon_{1}<2 \%$, the reconstituted specimen shows increases in $q$, while for the intact specimen the trends are more progressive. The generally softer response of the reconstituted specimen also led to a barrelling failure without any shear plane. While the intact specimen showed typically Isotach behaviour, the reconstituted specimen gave an Isotach response up to the peak $q$ and a tendency to a "Combined" type of behaviour for larger strains. There are significant differences also in terms of excess pore pressure. When accelerating from the initial rate ratio (10) to the faster one (100), the reconstituted specimen (M2) does not show the jump in pore pressure build-up observed in the intact specimen (M1). The responses to the subsequent decrease (100 to 1 ) in strain rate show the opposite: the reconstituted specimen exhibits a sharp pore pressure increase while the pore pressure in the intact specimen decreases markedly. The same trends were also observed in the post-peak regime. The $q-p$ ' effective stress paths reveal that the reconstituted specimen does not have the vertical initial section seen with intact specimens. This is partly due to the reconstituted specimen being normally consolidated, with no pre-consolidation stage being applied, while the initial structure of the intact specimens generated by ageing and other natural processes confers the apparent behaviour of overconsolidated soils (Le et al., 2008). The initial response of the reconstituted specimens, 
under a strain rate ratio of 10 , quickly reaches a plateau and follows a contracting phase until a step in strain rate ratio to 100 generates an increase in $q$. A post-peak reduction in rate ratio causes a sharp unloading and the final effective stress path tends towards that of the intact specimen. The maximum shear strength is reached, under the fast rate, at an equivalent effective friction angle of $40.5^{\circ}$.

Strain rate effects in undrained shear tests, specimens consolidated to a SHANSEP stress state Noting the strain limitations of the Bishop and Wesley cell, the SHANSEP stress states applied to the specimens from Site $\mathrm{Z}$ were designed to be equal to 3 times the in-situ stress state, while a ratio of 5 was applied in the case of the specimens from site M. The stress state used for consolidation is expressed in terms of a ratio to the in-situ vertical stress instead of a ratio to the in-situ yield stress. This differs from the conventional SHANSEP procedure but is consistent with previous studies devoted to the applicability of the SHANSEP procedure to study GoG clays behaviour (Le et al, 2008). Figure 5 shows the compression response obtained during consolidation of specimen $\mathrm{Z}_{5}$ (taken at $16.57 \mathrm{~m}, q=27 \mathrm{kPa}, p^{\prime}=30 \mathrm{kPa}$ ) to final conditions of $q=$ $81 \mathrm{kPa}, p^{\prime}=90 \mathrm{kPa}$. From an initially isotropic effective stress state, the specimen was taken to the in-situ effective stress state and then compressed under drained $K_{o}$ conditions (Figure 5a). The volume change response during compression is presented in Figure $5 \mathrm{~b}$, together with that seen in a constant effective stress creep phase (approx. $18.8 \mathrm{~h}$ ), which resulted in a volumetric strain of $3 \%$.

Figure 6a shows the results of undrained compression shear tests conducted in compression after the creep stages on specimens $Z_{5}(16.57 \mathrm{~m})$ and $\mathrm{Z8}(19.40 \mathrm{~m})$ together with an extension test carried out on specimen Z6 (also $19.40 \mathrm{~m}$ ); tests Z6 and Z8 had been compressed to higher 
effective stresses (see Table 1). The behaviours of $\mathrm{Z}_{5}$ and $\mathrm{Z} 8$ under variable strain rate test conditions are similar to that observed on the reconstituted specimen M6 (Figure 4), with rapid increases or decreases in pore water pressure at each rate change and a generally stronger response of the deepest specimen (Z8). The response is not precisely Isotach, since the curves corresponding to the different strain rates tend to converge towards a single trend when the axial strain increases, suggesting a form of "Combined" mode. The same kind of response is observed in extension on specimen Z6. The post-peak convergence of the different master curves becomes obvious in both extension and compression. The pore pressure response pre-peak (Figure $6 \mathrm{~b}$ ) to a rate ratio reduction from 100 to 1 in compression at $2 \%$ strain ( $\mathrm{Z}_{5}$ and $\mathrm{Z8}$ ) is to develop a sudden decrease followed by a progressive increase, while the reconstituted specimen showed a sudden increase followed by a progressive decrease. A sudden decrease in pore pressure was also observed at $2 \%$ when the strain rate ratio was reduced from 100 to 1.

The corresponding effective stress paths are presented in Figure 6c. The effective stress paths of compression tests $\mathrm{Z}_{5}$ and $\mathrm{Z} 8$ are comparable in shape, reflecting similar responses to strain rate changes. They fall within a maximum effective friction angle of $41.5^{\circ}$ and reduce below this value with increasing strain. Changes in strain rates are also very clear in extension, and the effective stress paths finally stabilise with an effective friction angle of $31^{\circ}$. The compression and extension tests Z8 and Z6 are compatible and allow a satisfactory determination of the shape of the combined limit state curves of the $\mathrm{OCR}=1$ SHANSEP specimens at various strain rates. An inclined shape of the limit state curve is observed, reflecting induced anisotropy due to the consolidation process.

\section{Discussion}

Study of deep marine sediments from the Gulf of Guinea, considering intact, reconstituted and 
SHANSEP consolidated specimens showed that the GoG sediments respond to strain rate changes in a principally Isotach fashion. It appeared possible to project, from the tests conducted at various rates, the stress strain curves corresponding to fixed strain rates under undrained shearing. Comparable behaviour has been observed under isotropic compression, although these tests were performed with fixed stress rates and thus changing strain rates.

The different stress-strain curves associated with each strain rate remain approximately parallel whatever the strain value, showing a spacing in terms of $q$ amounting to between $15 \%$ and $20 \%$ per log cycle. This range is consistent with, although perhaps slightly higher than, the rate dependencies noted in earlier studies on onshore deposits.

Effects of structure were also observed with a clear difference between the brittle response of the apparently overconsolidated intact specimens and the softer behaviour of reconstituted and SHANSEP specimens tested after normal consolidation. The effects of structure and apparent overconsolidation are clear when considering the stress paths in $q / p$ ' space. A clear initial quasi-vertical effective stress path was observed for intact specimens which contrasts with the contractant paths followed by the normally consolidated reconstituted and SHANSEP consolidated specimens.

Concerning the coupling between structure and strain rate dependency, it was observed that the latter specimens tended to diverge from ideal Isotach behaviour post-peak and show a Combined response mode at larger strains, as was seen on high OCR London clay by Sorensen et al. (2007, 2010).

The effects of strain rate changes on excess pore pressure differed between the intact and the normally consolidated reconstituted and SHANSEP specimens. Whereas decreases in strain rate led to sudden decreases in pore pressure for the intact specimens, the reconstituted and 
SHANSEP consolidated specimens exhibited significant increases followed by a subsequent decrease.

\section{CONCLUSION}

An experimental programme has been carried out on high quality Gulf of Guinea (GoG) marine sediments specimens. These sediments are characterised by relatively high sensitivities and void ratios.

- A series of isotropic compression and triaxial tests from in-situ and SHANSEP stress conditions have shown that the mechanical behaviour of these sediments is strain rate dependent.

- It has been shown that the measured undrained $q-\varepsilon_{1}$ relationships follow a principally Isotach-type viscous response.

- Effects of soil structure and its degradation with strain have been observed and confirm general trends for low OCR clays. A brittle response is observed for intact specimens whereas the normally consolidated reconstituted and SHANSEP specimens show a softer response.

- The role of microstructure on the strain rate dependency of the stress-strain behaviour confirms previous studies on structured clays. The degradation of the initial structure (by reconstitution or normal consolidation to high stresses) tends to make the soil response switch from a mainly Isotach behaviour to a more complex viscous behaviour, characterised by an Isotach mode pre-peak and a Combined mode post-peak.

- A significant role of microstructure has also been observed in terms of the pore pressure 
response to strain rate changes. The intact specimens have an opposite response to the normally consolidated reconstituted and SHANSEP.

\section{ACKNOWLEDGMENTS}

The samples used in this project were provided by FUGRO France. The authors are grateful for the funding provided under the CITEPH funding framework (project CITEPH-23-24-2008). Permission to publish this paper is gratefully acknowledged. The authors would like to thank Dr. Béatrice Baudet of the University of Hong Kong, for her constructive discussion on the project.

\section{REFERENCES}

Acosta-Martinez, H., Tatsuoka, F. and Li, J. (2003). Viscosity in one-dimensional deformation of clay and considerations for its modelling. Proc. 38th Jpn. Nat. Conf. Geotech. Engng., Akita, $255-256$.

Alberro, J. and Santoyo, E. (1973). Long term behavior of Mexico City clay. Proceedings $8^{\text {th }}$ International Conference on Soil Mechanics and Foundation Engineering, Vol. 1.1, 1-9.

Bishop, A. and Wesley, L. (1975). A hydraulic triaxial apparatus for controlled stress path testing, Geotechnique 25 (4), 657-670.

Borel, D., Puech, A., Dendani, H. and Colliat, J. (2005). Deepwater geotechnical site investigation practice in the Gulf of Guinea, International Seminar on Frontiers in Offshore Geotechnics, ISFOG. Perth, 921-926.

Casagrande, A. and Wilson, S. (1950). Effect of rate of loading on the strength of clays and shales, Geotechnique 2, 251-263. 
Colliat J.L., Dendani H., Puech A. and Nauroy J.F. (2010). Gulf of Guinea deepwater sediments: Geotechnical properties, design issues and installation experiences, in Proc. 2nd International Symposium on Frontiers in Offshore Geotechnics, Perth, Australia.

Diaz-Rodriguez, J., Martinez-Vasquez, J. and Santamarina, J. (2009). Strain-rate effects in Mexico City soil, Journal of Geotechnical and Geoenvironmental Engineering 135 (2), 300-305. Filz, G., Henry, L., Heslin, G. and Davidson, R. (2001). Determining hydraulic conductivity of soil-bentonite using the api filter press, Geotechnical Testing Journal 24 (1), 61-71.

Graham, J., Crooks, J. and Bell, A. (1983). Time effects on the stress-strain behaviour of natural soft clays, Geotechnique $\mathbf{3 3}$ (3), 327-340.

Jung, M., Chea, J. and Shibuya, S. (2009). Effects of shear rate and consolidation time on undrained behavior of natural sedimentary clay. Journal of Korean Geotechnical Society 25 (3), $5-12$.

Komoto, N., Tatsuoka, F. and Nishi, T (2003). Viscous stress-strain properties of undisturbed Pleistocene clay and its constitutive modeling, in Proc. $3^{\text {rd }}$ Int. Sym. on Deformation Characteristics of Geomaterials, pp.579-587

Ladd, C.C., and Foott, R. (1974). New Design Procedure for Stability of Soft Clays. Journal of the Geotechnical Engineering Division, ASCE 100(7), 767-787.

Le, M., Nauroy, J., De Gennaro, V., Delage, P., Flavigny, E., Thanh, N., Colliat, J., Puech, A. and Meunier, J. (2008). Characterization of soft deepwater West Africa clays: Shansep testing is not recommended for sensitive structured clays. Offshore Technology Conference, Houston, Texas, USA.

Lefebvre, G. and LeBoeuf, D. (1987). Rate effects and cyclic loading of sensitive clays, Journal of 
Geotechnical Engineering 113 (5), 476-489.

Leroueil, S., Perret, D. and Locat, J. (1996). Strain rate and structuring effects on the compressibility of a young clay, ASCE Geotechnical Special Publication 61, 137-150.

Puech, A., Colliat, J., Nauroy, J. and Meunier, J. (2005). Some geotechnical specificities of Gulf of Guinea deepwater sediments, Proceedings of the First International Symposium on Frontiers in Offshore Geotechnics (ISFOG). Balkema, Perth, 1047-1053.

Rattley, M. J., Hill, A.J., Thomas, S. and Sampurno, B. (2010) Strain rate dependent simple shear behavior of deepwater sediments in offshore Angola, in Proc. 2nd International Symposium on Frontiers in Offshore Geotechnics, Perth, Australia.

Richardson, A. and Whitman, R. (1963). Effect of strain rate upon undrained strain resistance of a saturated remoulded fat clay, Geotechnique $\mathbf{1 3}$ (3), 310-324.

Sorensen, K., Baudet, B. and Simpson, B. (2007). Influence of structure on the time-dependent behaviour of a stiff sedimentary clay, Geotechnique 57 (1), 113-124.

Sorensen, K., Baudet, B. and Simpson, B. (2010). Influence of strain rate and acceleration on the behaviour of reconstituted clays at small strains, Geotechnique $\mathbf{6 0}$ (10), 751-763.

Tatsuoka, F. (2007). Inelastic deformation characteristics of geomaterial. Soil Stress-Strain Behavior: Measurement, Modeling and Analysis, Proc. Geotechnical Symposium in Roma, $1-108$.

Tatsuoka, F., Ishihara, M., Di Benedetto, H. and Kuwano, R. (2002). Time-dependent shear deformation characteristics of geomaterials and their simulation, Soils and Foundations 42 (2), $103-129$.

Thomas, F., Rebours, B., Nauroy, J.-F. \& Meunier, J. (2005). Mineralogical characteristics of the 
Gulf of Guinea deep water sediments. Proc. Int. Symp. Frontiers in Offshore Geotechnics, Perth, $1055-1061$.

Vaid, Y. and Campanella, R. (1977). Time-dependent behaviour of undisturbed clay, ASCE Journal of Geotechnical Division 103 (GT7), 693-709.

Zhu, J. and Yin, J. (2000). Strain-rate-dependent stress-strain behavior of overconsolidated Hong Kong marine clay, Canadian Geotechnical Journal 37, 1272-1282. 


\section{LIST OF TABLES}

Table 1. Tests performed on intact and reconstituted specimens from Sites Z and M

\begin{tabular}{|c|c|c|c|c|}
\hline $\begin{array}{l}\text { Specimen no } \\
\text { \& type }\end{array}$ & $\begin{array}{l}\text { Boring \& } \\
\text { Depth below } \\
\text { seabed }(\mathrm{m})\end{array}$ & $\begin{array}{l}\text { Stresses during } \\
\text { saturation } \\
\text { process }\end{array}$ & Test type & $\begin{array}{l}\text { Consolidation (stress } \\
\text { state, volumetric strain, } \\
\text { creep time) }\end{array}$ \\
\hline $\begin{array}{l}\mathrm{Z} 2 \\
\text { intact }\end{array}$ & $\begin{array}{l}\text { ST-Mo6-S1 } \\
16.72\end{array}$ & $\begin{array}{l}\sigma_{1}=\sigma_{3}=320 \mathrm{kPa} \\
\mathrm{u}=307 \mathrm{kPa} \\
\left(\sigma_{1}^{\prime}=\sigma_{3}{ }^{\prime}=13 \mathrm{kPa}\right)\end{array}$ & $\begin{array}{l}\text { CAUc (strain } \\
\text { rates: } 0.05 \text {, } \\
0.5,5 \% / \mathrm{hr} \text { ) }\end{array}$ & $\begin{array}{l}\text { In-situ state, } \mathrm{p}^{\prime}=31 \mathrm{kPa} \\
\mathrm{q}=26 \mathrm{kPa} \\
\varepsilon_{\mathrm{vol} \mathrm{TOTAL}}=1.9 \%, \\
\varepsilon_{\mathrm{vol} \text { creep }}=0.4 \%, \text { creep } \\
\text { duration: } 8,5 \mathrm{~h}\end{array}$ \\
\hline $\begin{array}{l}Z_{3} \\
\text { intact }\end{array}$ & $\begin{array}{l}\text { ST-M11-S2O } \\
19 \cdot 32\end{array}$ & $\begin{array}{l}\sigma_{1}=\sigma_{3}=320 \mathrm{kPa} \\
\mathrm{u}=310 \mathrm{kPa} \\
\left(\sigma_{1}^{\prime}=\sigma_{3}^{\prime}=10 \mathrm{kPa}\right)\end{array}$ & \multicolumn{2}{|c|}{$\begin{array}{l}\text { Isotropic compression (loading rates: } 0.5 \text {, } \\
1,5 \mathrm{kPa} / \mathrm{hr} \text { ) }\end{array}$} \\
\hline $\begin{array}{l}\mathrm{Z}_{4} \\
\text { intact }\end{array}$ & $\begin{array}{l}\text { ST-M11-S20 } \\
19 \cdot 32\end{array}$ & $\begin{array}{l}\sigma_{1}=\sigma_{3}=320 \mathrm{kPa} \\
\mathrm{u}=310 \mathrm{kPa} \\
\left(\sigma_{1}^{\prime}=\sigma_{3}{ }^{\prime}=1 \mathrm{okPa}\right)\end{array}$ & \multicolumn{2}{|c|}{$\begin{array}{l}\text { Isotropic compression (loading rate: } \\
5 \mathrm{kPa} / \mathrm{hr} \text { ) }\end{array}$} \\
\hline $\begin{array}{l}\mathrm{Z}_{5} \\
\text { intact }\end{array}$ & $\begin{array}{l}\text { ST-M11-S17 } \\
16.57\end{array}$ & $\begin{array}{l}\sigma_{1}=\sigma_{3}=324 \mathrm{kPa} \\
\mathrm{u}=310 \mathrm{kPa} \\
\left(\sigma_{1}^{\prime}=\sigma_{3}{ }^{\prime}=14 \mathrm{kPa}\right)\end{array}$ & $\begin{array}{l}\text { CAUc (strain } \\
\text { rates: } 0.05 \text {, } \\
0.5,5 \% / h r \text { ) }\end{array}$ & $\begin{array}{l}\text { SHANSEP, } \mathrm{p}^{\prime}=90 \mathrm{kPa} \\
\mathrm{q}=81 \mathrm{kPa} \\
\varepsilon_{\mathrm{vol}} \mathrm{TOTAL}=16.1 \%, \\
\varepsilon_{\text {vol creep }}=3 \%, \text { creep } \\
\text { duration: } 18,8 \mathrm{~h}\end{array}$ \\
\hline $\begin{array}{l}\text { Z6 } \\
\text { intact }\end{array}$ & $\begin{array}{l}\text { ST-Mo6-S2 } \\
\text { o } \\
19.40\end{array}$ & $\begin{array}{l}\sigma_{1}=\sigma_{3}=320 \mathrm{kPa} \\
\mathrm{u}=305 \mathrm{kPa} \\
\left(\sigma_{1}^{\prime}=\sigma_{3}{ }^{\prime}=15 \mathrm{kPa}\right)\end{array}$ & $\begin{array}{l}\text { CAUe (strain } \\
\text { rates: } 0.05 \text {, } \\
0.5,5 \% / \mathrm{hr} \text { ) }\end{array}$ & $\begin{array}{l}\text { SHANSEP, } \mathrm{p}^{\prime}=108 \mathrm{kPa} \\
\mathrm{q}=93 \mathrm{kPa} \\
\varepsilon_{\mathrm{vol} \mathrm{TOTAL}}=21.8 \%, \\
\varepsilon_{\text {vol creep }}=2.3 \%, \text { creep } \\
\text { duration: } 33 \mathrm{~h}\end{array}$ \\
\hline $\begin{array}{l}\mathrm{Z}_{7} \\
\text { reconstituted }\end{array}$ & $\begin{array}{l}\text { ST-Mo6-S18 } \\
16.72\end{array}$ & $\begin{array}{l}\sigma_{1}=\sigma_{3}=320 \mathrm{kPa} \\
\mathrm{u}=310 \mathrm{kPa} \\
\left(\sigma_{1}^{\prime}=\sigma_{3}{ }^{\prime}=10 \mathrm{kPa}\right)\end{array}$ & \multicolumn{2}{|c|}{$\begin{array}{l}\text { Isotropic compression (loading rates: } 0.5 \text {, } \\
1,5 \mathrm{kPa} / \mathrm{hr} \text { ) }\end{array}$} \\
\hline $\begin{array}{l}\mathrm{Z} 8 \\
\text { intact }\end{array}$ & $\begin{array}{l}\text { ST-Mo6-S2 } \\
\text { o } \\
19.40\end{array}$ & $\begin{array}{l}\sigma_{1}=\sigma_{3}=325 \mathrm{kPa} \\
\mathrm{u}=310 \mathrm{kPa} \\
\left(\sigma_{1}^{\prime}=\sigma_{3}{ }^{\prime}=15 \mathrm{kPa}\right)\end{array}$ & $\begin{array}{l}\text { CAUc (strain } \\
\text { rates: } 0.05 \text {, } \\
0.5,5 \% / \mathrm{hr} \text { ) }\end{array}$ & $\begin{array}{l}\text { SHANSEP, } \mathrm{p}^{\prime}=108 \mathrm{kPa} \\
\mathrm{q}=93 \mathrm{kPa} \\
\varepsilon_{\mathrm{vol}} \text { TOTAL }=18.1 \%, \\
\varepsilon_{\mathrm{vol} \text { creep }}=1.8 \%, \text { creep } \\
\text { duration: } 19.5 \mathrm{~h}\end{array}$ \\
\hline $\begin{array}{l}\text { M1 } \\
\text { intact }\end{array}$ & $\begin{array}{l}\mathrm{BH}-\mathrm{M}-\mathrm{S} 1 \\
15 \cdot 72\end{array}$ & $\begin{array}{l}\sigma_{1}=\sigma_{3}=320 \mathrm{kPa} \\
\mathrm{u}=305 \mathrm{kPa} \\
\left(\sigma_{1}^{\prime}=\sigma_{3}{ }^{\prime}=15 \mathrm{kPa}\right)\end{array}$ & $\begin{array}{l}\text { CAUc (strain } \\
\text { rates: } 0.05 \text {, } \\
0.5,5 \% / \mathrm{hr} \text { ) }\end{array}$ & $\begin{array}{l}\text { in-situ state }, \mathrm{p}^{\prime}=35 \mathrm{kPa} \\
\mathrm{q}=29 \mathrm{kPa} \\
\varepsilon_{\text {vol TOTAL }}=1.5 \% \\
\varepsilon_{\text {vol creep }}=0.2 \%, \text { creep } \\
\text { duration: } 4 \mathrm{~h}\end{array}$ \\
\hline $\begin{array}{l}\text { M2 } \\
\text { intact }\end{array}$ & $\begin{array}{l}\text { BH-M-So6 } \\
11.35\end{array}$ & $\begin{array}{l}\sigma_{1}=\sigma_{3}=320 \mathrm{kPa} \\
\mathrm{u}=310 \mathrm{kPa} \\
\left(\sigma_{1}^{\prime}=\sigma_{3}{ }^{\prime}=1 \mathrm{okPa}\right)\end{array}$ & \multicolumn{2}{|c|}{$\begin{array}{l}\text { Isotropic compression (loading rate: } \\
5 \mathrm{kPa} / \mathrm{hr} \text { ) }\end{array}$} \\
\hline $\begin{array}{l}\text { M3 } \\
\text { intact }\end{array}$ & $\begin{array}{l}\text { BH-M-So6 } \\
11.35\end{array}$ & $\begin{array}{l}\sigma_{1}=\sigma_{3}=320 \mathrm{kPa} \\
\mathrm{u}=310 \mathrm{kPa} \\
\left(\sigma_{1}^{\prime}=\sigma_{3}{ }^{\prime}=1 \mathrm{okPa}\right)\end{array}$ & \multicolumn{2}{|c|}{$\begin{array}{l}\text { Isotropic compression (loading rates: } 0.5 \text {, } \\
1,5 \mathrm{kPa} / \mathrm{hr} \text { ) }\end{array}$} \\
\hline
\end{tabular}




\begin{tabular}{|c|c|c|c|c|}
\hline $\begin{array}{l}\text { M4 } \\
\text { intact }\end{array}$ & $\begin{array}{l}\text { BH-M-So6 } \\
11.23\end{array}$ & $\begin{array}{l}\sigma_{1}=\sigma_{3}=320 \mathrm{kPa} \\
\mathrm{u}=309 \mathrm{kPa} \\
\left(\sigma_{1}{ }^{\prime}=\sigma_{3}{ }^{\prime}=11 \mathrm{kPa}\right)\end{array}$ & $\begin{array}{l}\text { CAUc (strain } \\
\text { rates: } 0.05 \text {, } \\
0.5,5 \% / \mathrm{hr} \text { ) }\end{array}$ & $\begin{array}{l}\text { SHANSEP, } \mathrm{p}^{\prime}=120 \mathrm{kPa} \\
\mathrm{q}=105 \mathrm{kPa} \\
\varepsilon_{\mathrm{vol}} \text { тотAL }=22.2 \%, \\
\varepsilon_{\mathrm{vol} \text { creep }}=0.8 \%, \text { creep } \\
\text { duration: } 8 \mathrm{~h}\end{array}$ \\
\hline $\begin{array}{l}\text { M5 } \\
\text { intact }\end{array}$ & $\begin{array}{l}\text { BH-M-S1 } \\
15.86\end{array}$ & $\begin{array}{l}\sigma_{1}=\sigma_{3}=325 \mathrm{kPa} \\
\mathrm{u}=310 \mathrm{kPa} \\
\left(\sigma_{1}^{\prime}=\sigma_{3}{ }^{\prime}=15 \mathrm{kPa}\right)\end{array}$ & $\begin{array}{l}\text { CAUe (strain } \\
\text { rates: } 0.05 \text {, } \\
0.5,5 \% / \mathrm{hr} \text { ) }\end{array}$ & $\begin{array}{l}\text { SHANSEP, } \mathrm{p}^{\prime}=173 \mathrm{kPa} \\
\mathrm{q}=145 \mathrm{kPa} \\
\varepsilon_{\mathrm{vol}} \text { тотAL }=23 \%, \\
\varepsilon_{\mathrm{vol} \text { creep }}=0.9 \%, \text { creep } \\
\text { duration: } 8.5 \mathrm{~h}\end{array}$ \\
\hline $\begin{array}{l}\text { M6 } \\
\text { reconstituted }\end{array}$ & $\begin{array}{l}\mathrm{BH}-\mathrm{M}-\mathrm{S} 1 \\
16.72\end{array}$ & $\begin{array}{l}\sigma_{1}=\sigma_{3}=320 \mathrm{kPa} \\
\mathrm{u}=306 \mathrm{kPa} \\
\left(\sigma_{1}^{\prime}=\sigma_{3}{ }^{\prime}=14 \mathrm{kPa}\right)\end{array}$ & $\begin{array}{l}\text { CAUc (strain } \\
\text { rates: } 0.05 \text {, } \\
0.5,5 \% / h r \text { ) }\end{array}$ & $\begin{array}{l}\text { in-situ state, } \mathrm{p}^{\prime}=35 \mathrm{kPa} \\
\mathrm{q}=29 \mathrm{kPa}) \\
\varepsilon_{\text {vol TOTAL }}=4.28 \% \\
\end{array}$ \\
\hline $\begin{array}{l}\text { M7 } \\
\text { intact }\end{array}$ & $\begin{array}{l}\text { BH-M-So6 } \\
11.23\end{array}$ & $\begin{array}{l}\sigma_{1}=\sigma_{3}=320 \mathrm{kPa} \\
\mathrm{u}=310 \mathrm{kPa} \\
\left(\sigma_{1}^{\prime}=\sigma_{3}{ }^{\prime}=1 \mathrm{okPa}\right)\end{array}$ & $\begin{array}{l}\text { CAUc (strain } \\
\text { rates: } 0.05 \text {, } \\
0.5,5 \% / \mathrm{hr} \text { ) }\end{array}$ & $\begin{array}{l}\text { in-situ state, } \mathrm{p}^{\prime}=24 \mathrm{kPa} \\
\mathrm{q}=21 \mathrm{kPa}) \\
\varepsilon_{\mathrm{vol}} \text { тотАL }=1 \%, \\
\varepsilon_{\mathrm{vol} \text { creep }}=0.16 \%, \text { creep } \\
\text { duration: } 7 \mathrm{~h}\end{array}$ \\
\hline
\end{tabular}




\section{LIST OF FIGURES}

Figure 1. Stress rate effect, drained isotropic compression tests on intact specimens $Z$ (19.32m, a) and $\mathrm{M}(11.35 \mathrm{~m}, \mathrm{~b})$

Figure 2. Strain rate effects in the change of deviator stress (a) and excess pore pressure (b) with axial strain; (c) stress path followed in the $q-p^{\prime}$ plane (intact specimen, Site M)

Figure 3. Strain rate effects in the change of deviator stress (a) and excess pore pressure (b) with axial strain; (c) stress path followed in the $q$-p' plane (intact specimen, Site Z)

Figure 4. Effect of destructuration on the strain rate effects in the change of deviator stress (a) and excess pore pressure (b) with axial strain; (c) stress path followed in the $q-p$ ' plane (intact and reconstituted specimen, Site $\mathrm{M}$ )

Figure 5 Consolidation under SHANSEP state (a) $q-p^{\prime}$ curve (b) volume changes with changes in $p^{\prime}, K_{o}$ compression.

Figure 6. Strain rate effects in the change of deviator stress (a) and excess pore pressure (b) with axial strain; (c) stress path followed in the $q$ - $p$ ' plane (SHANSEP specimens Z5, Z6 and Z8). 


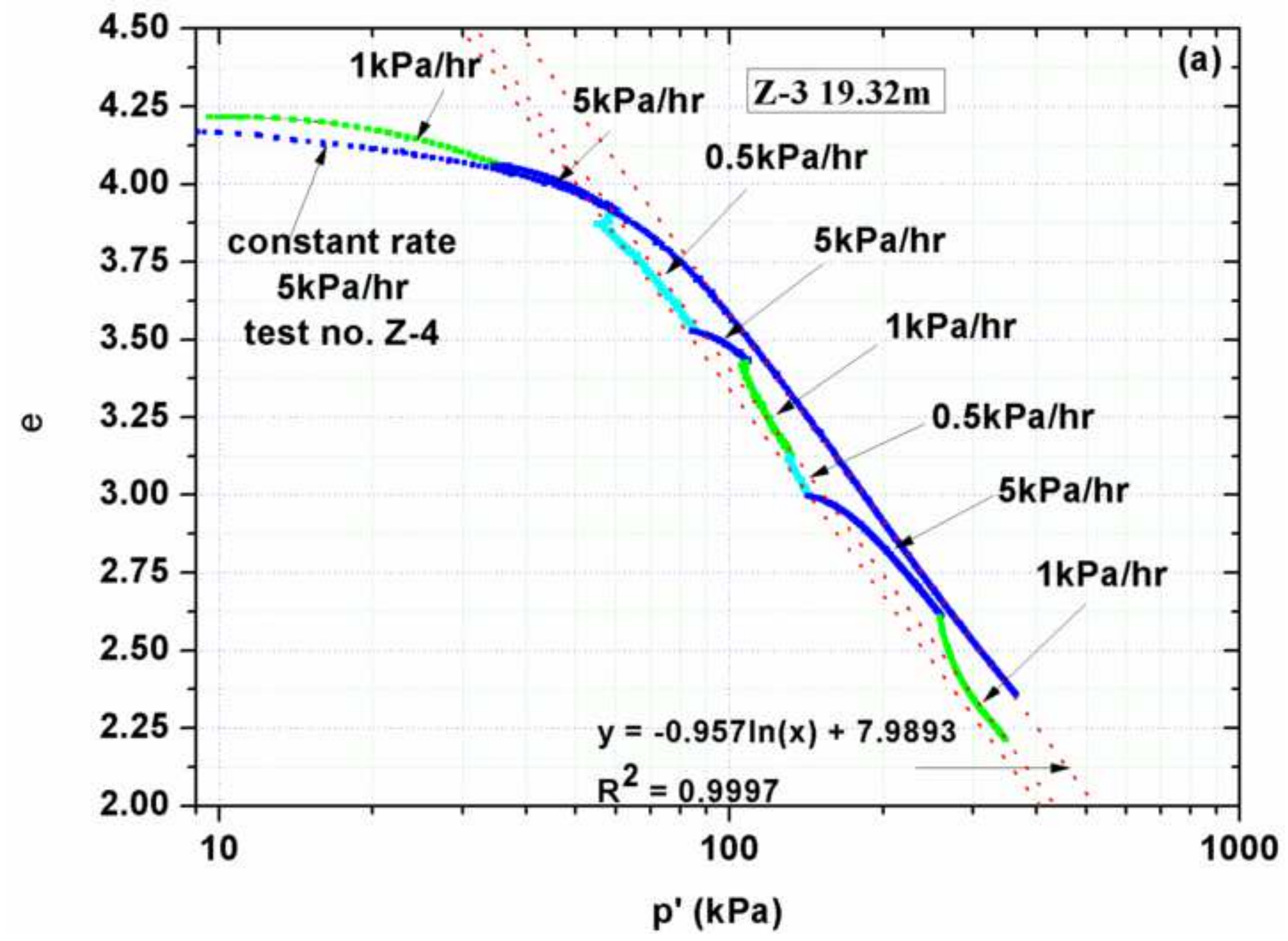




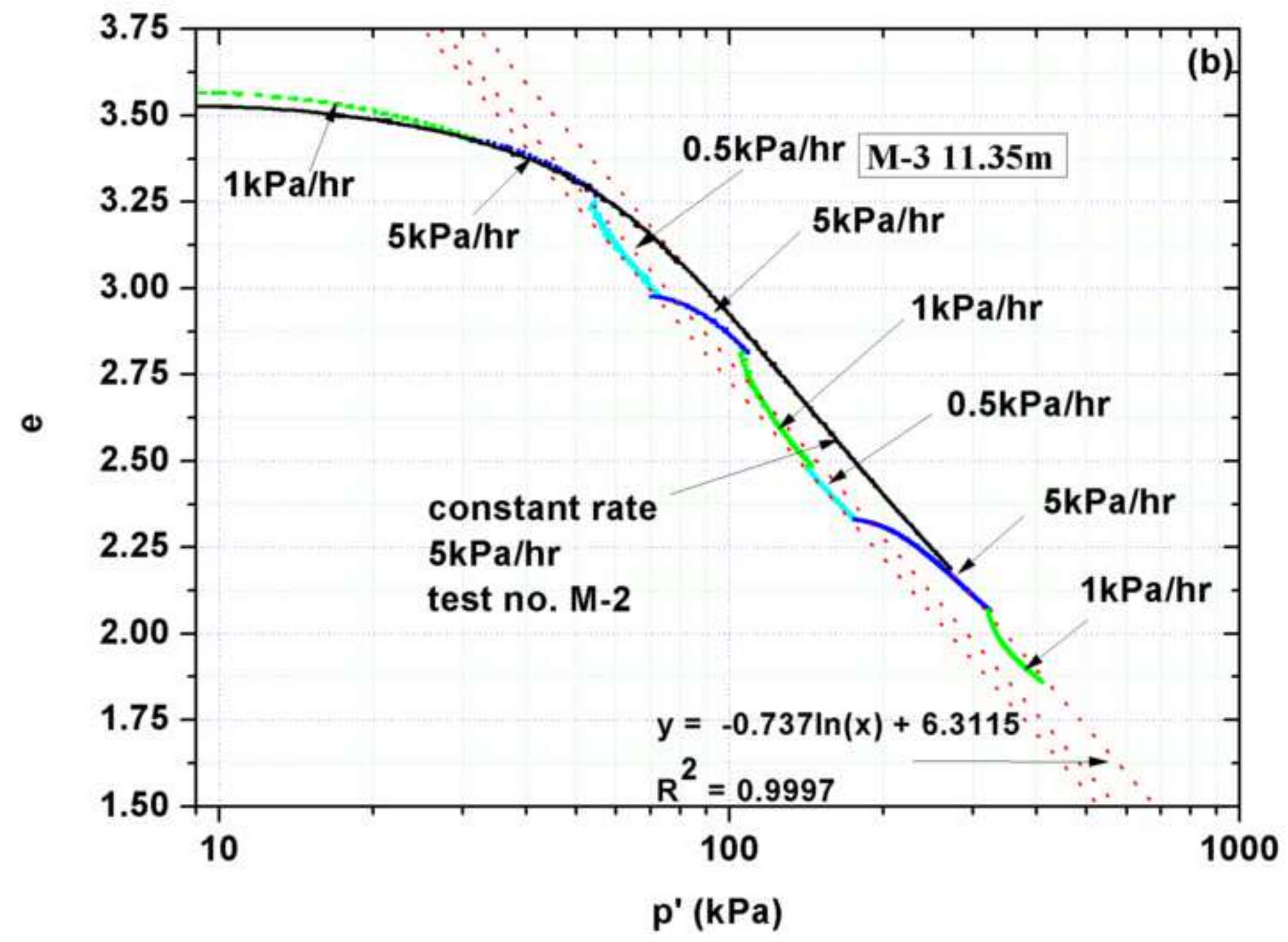




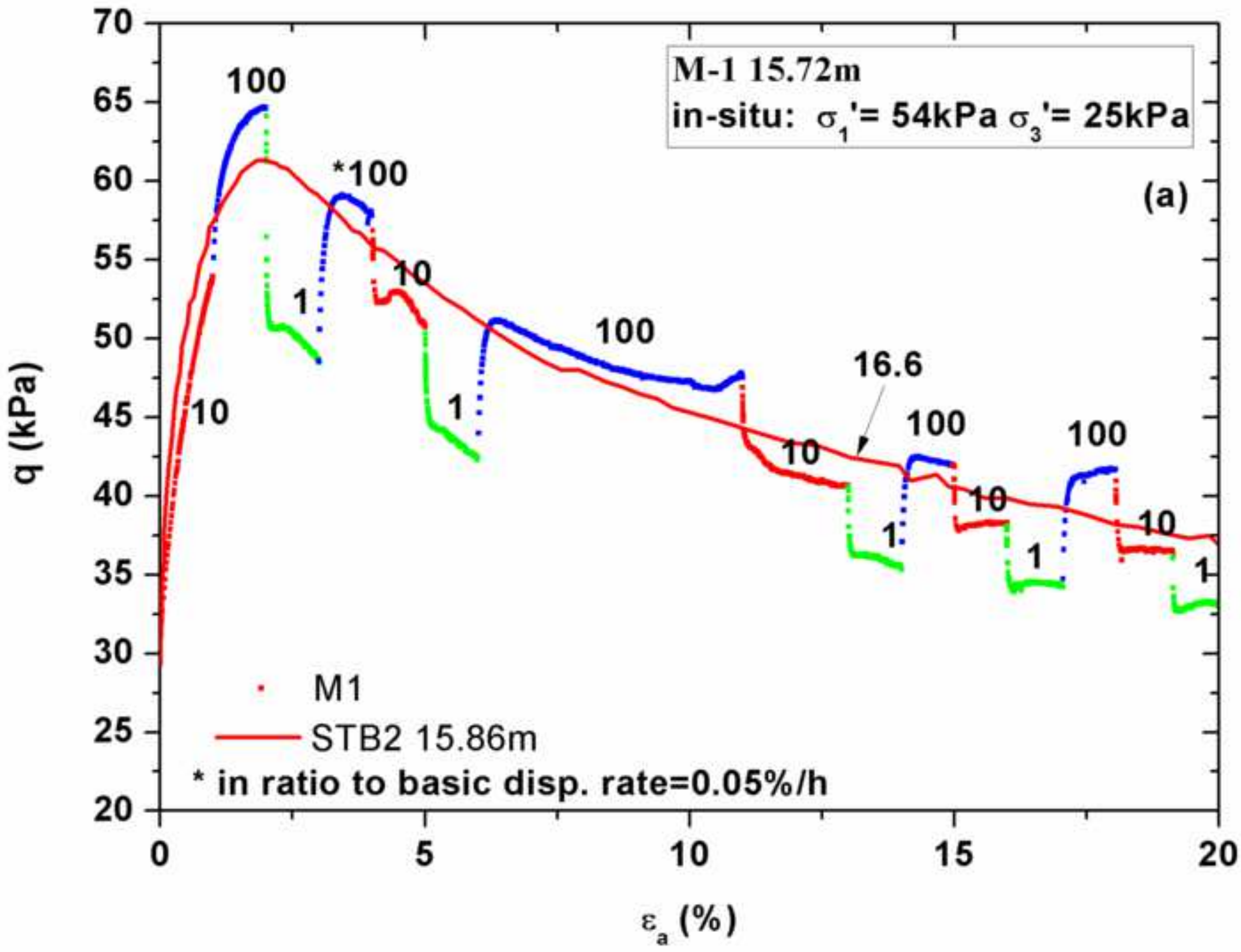




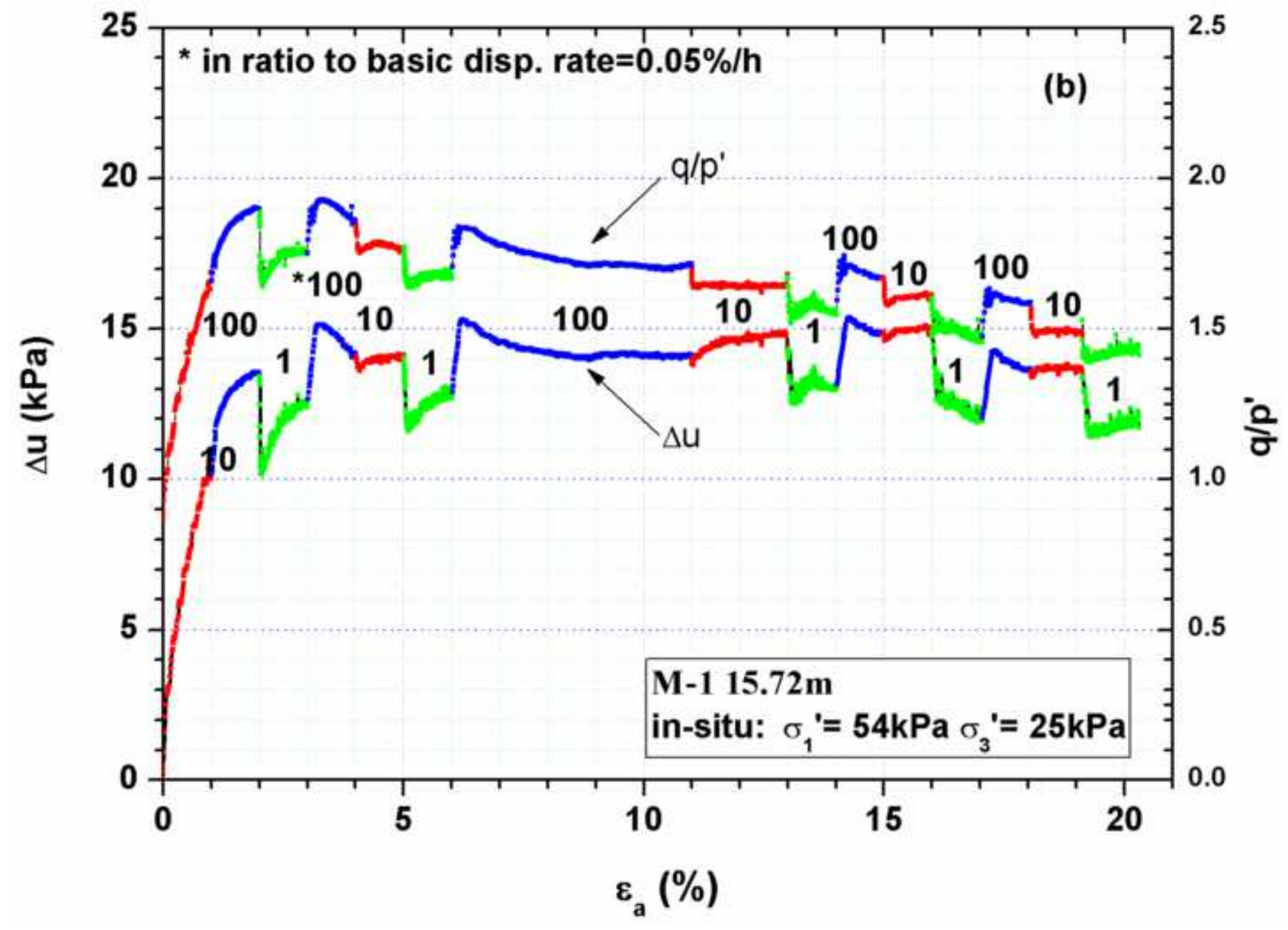




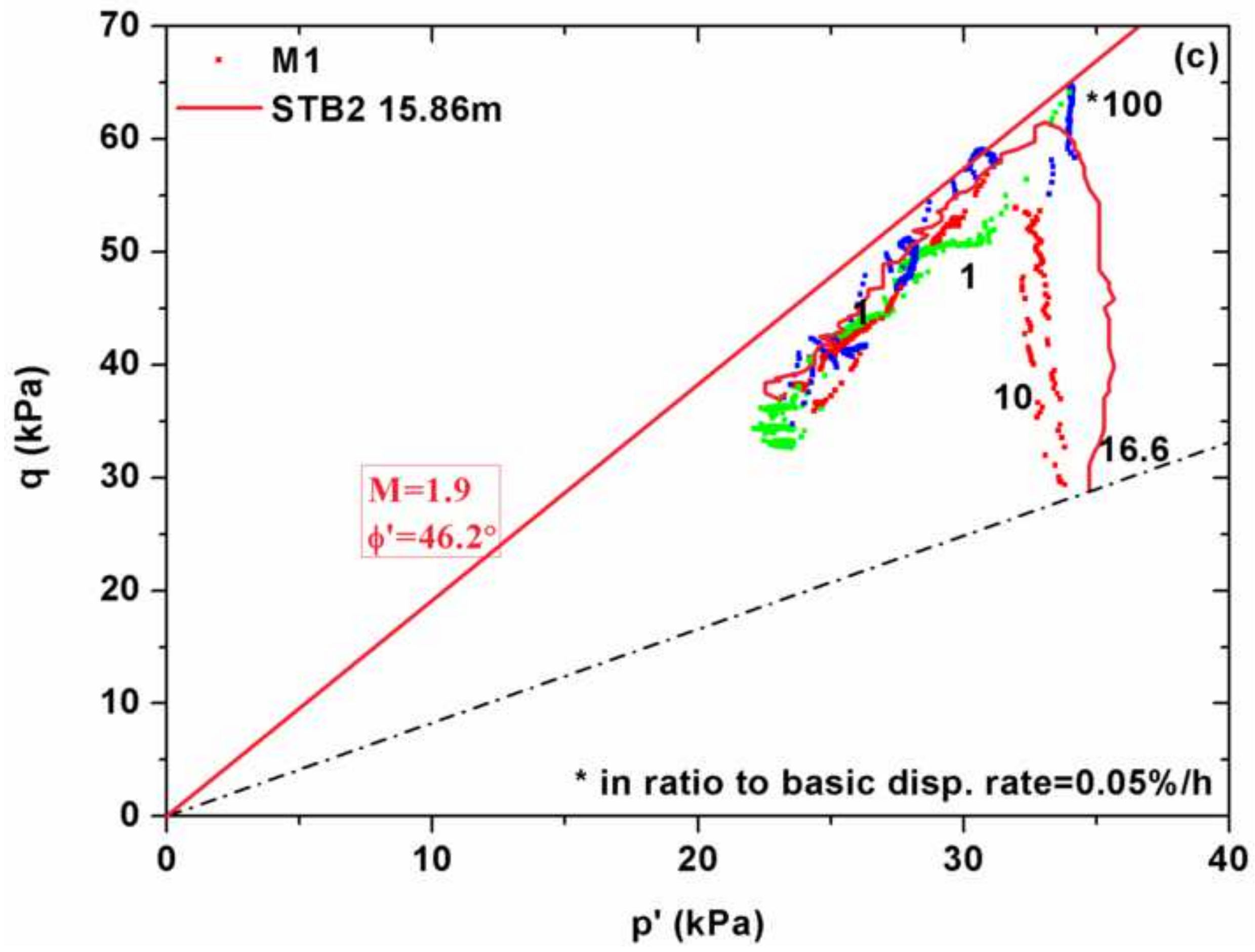




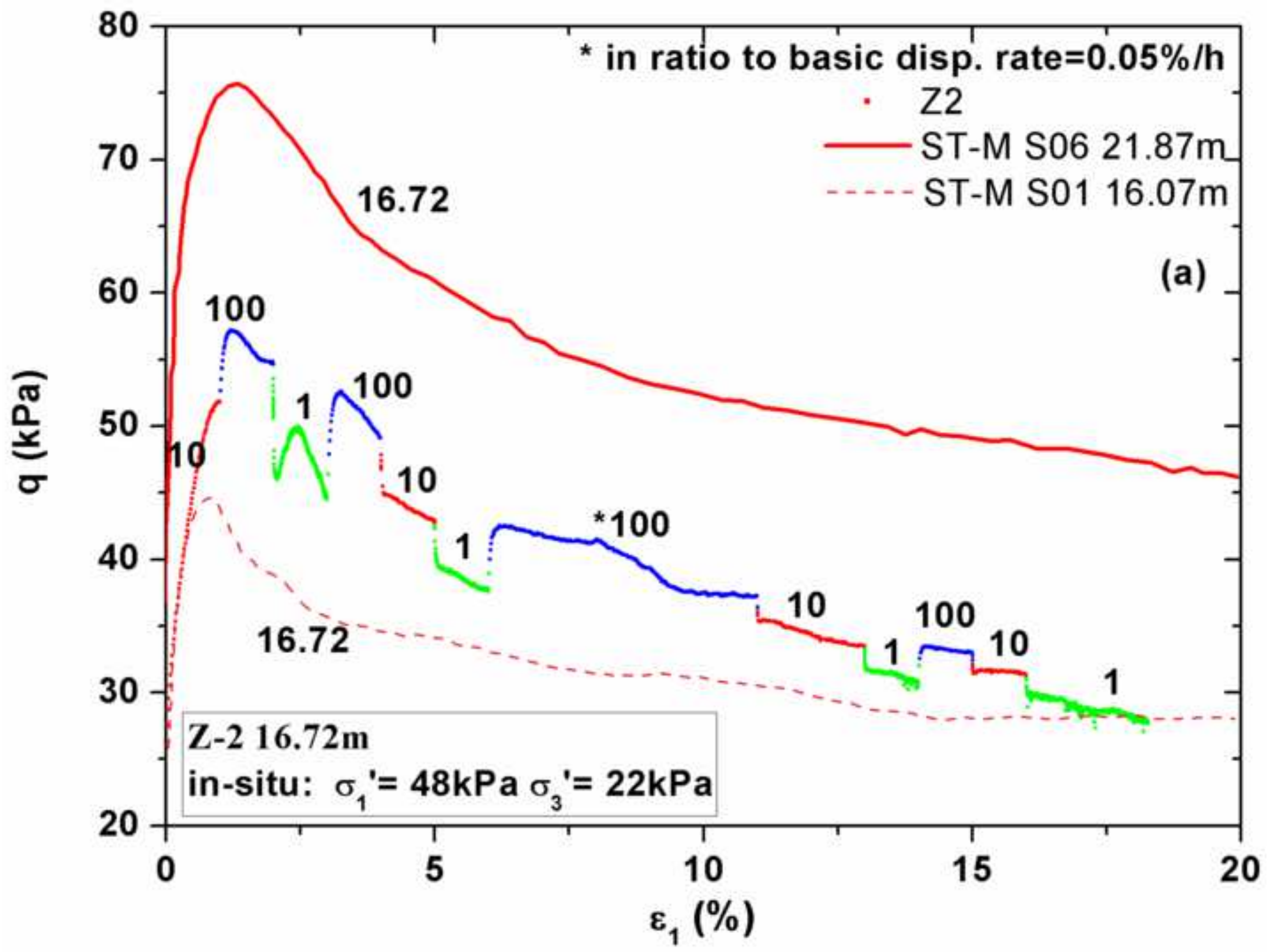




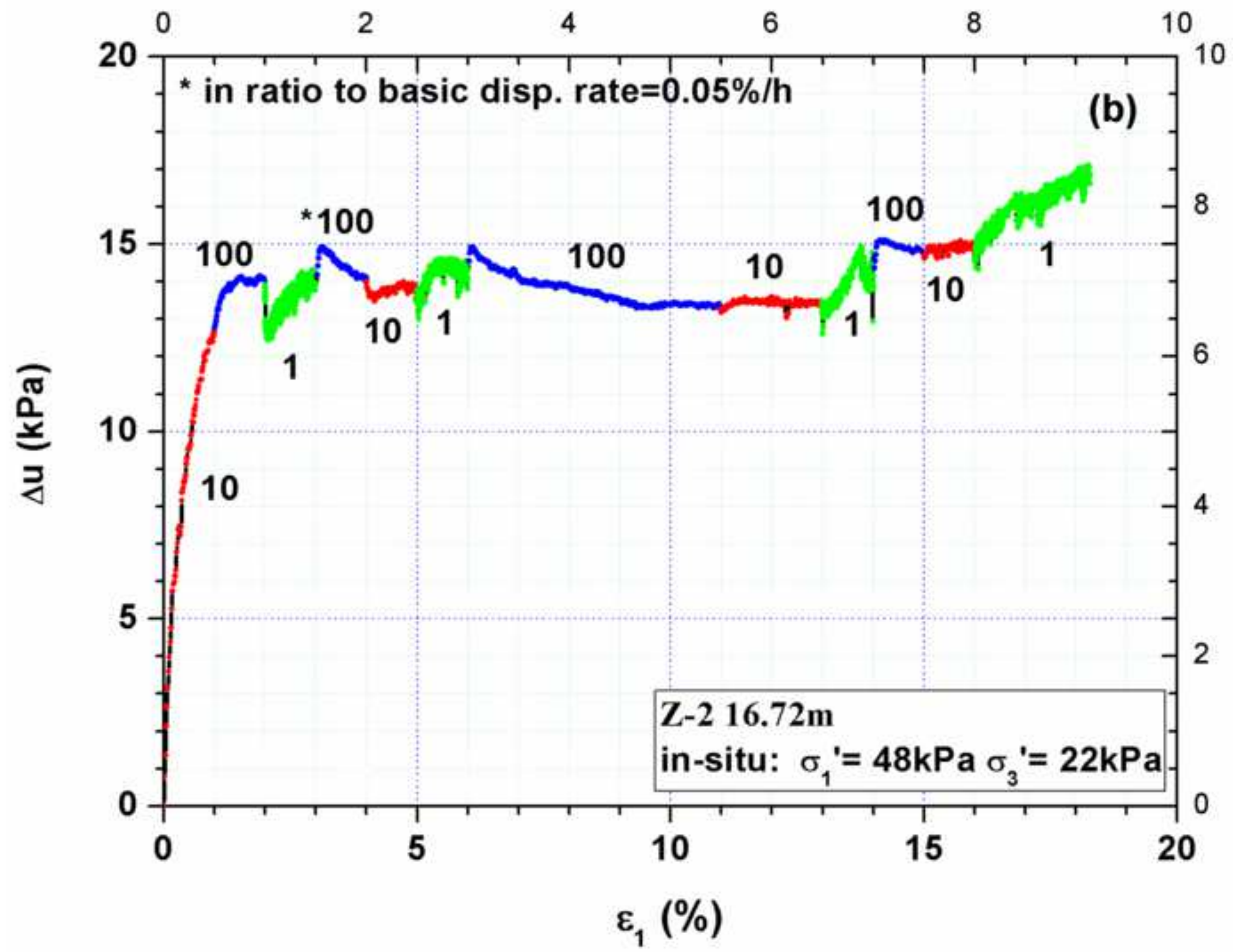




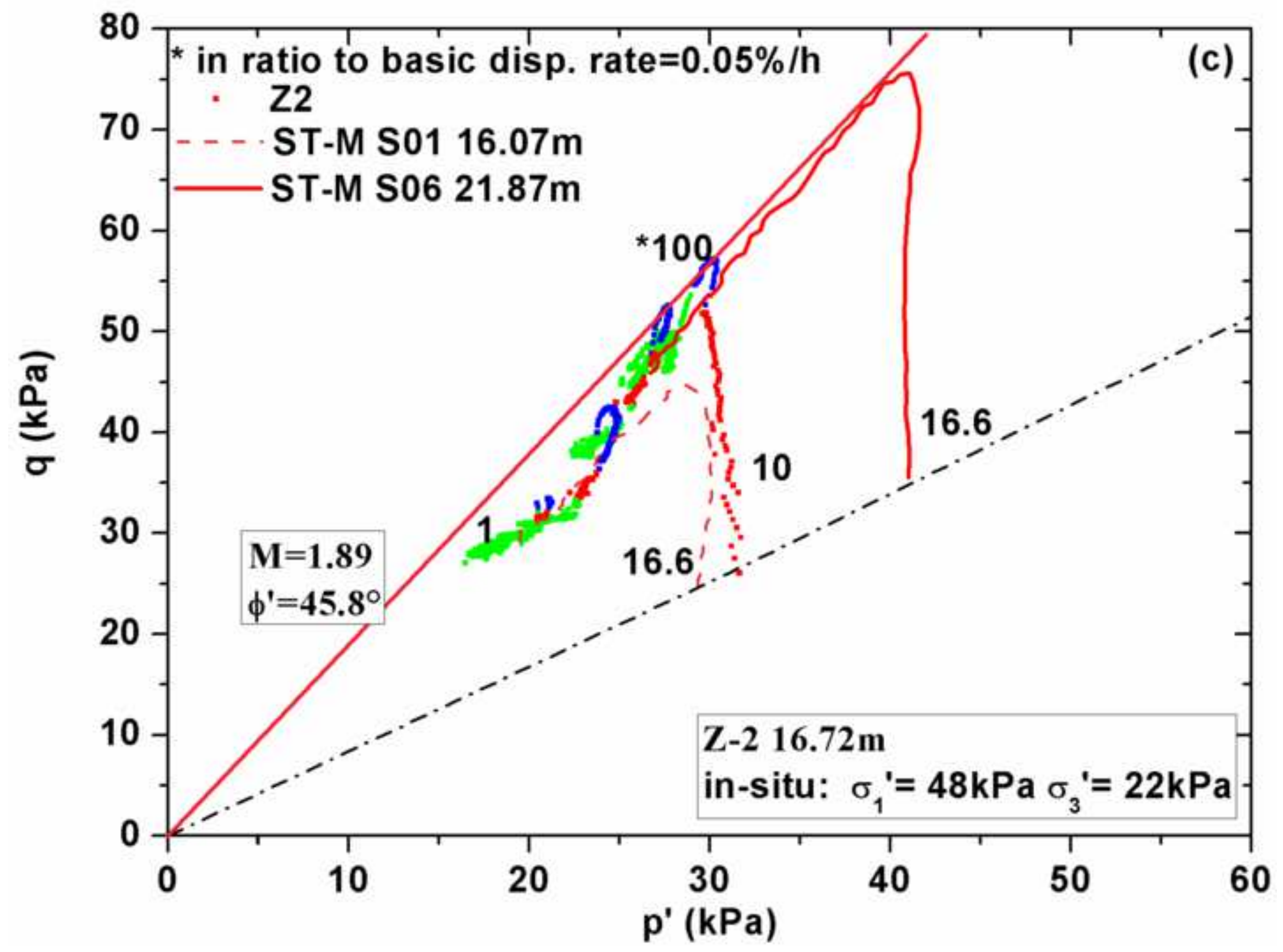




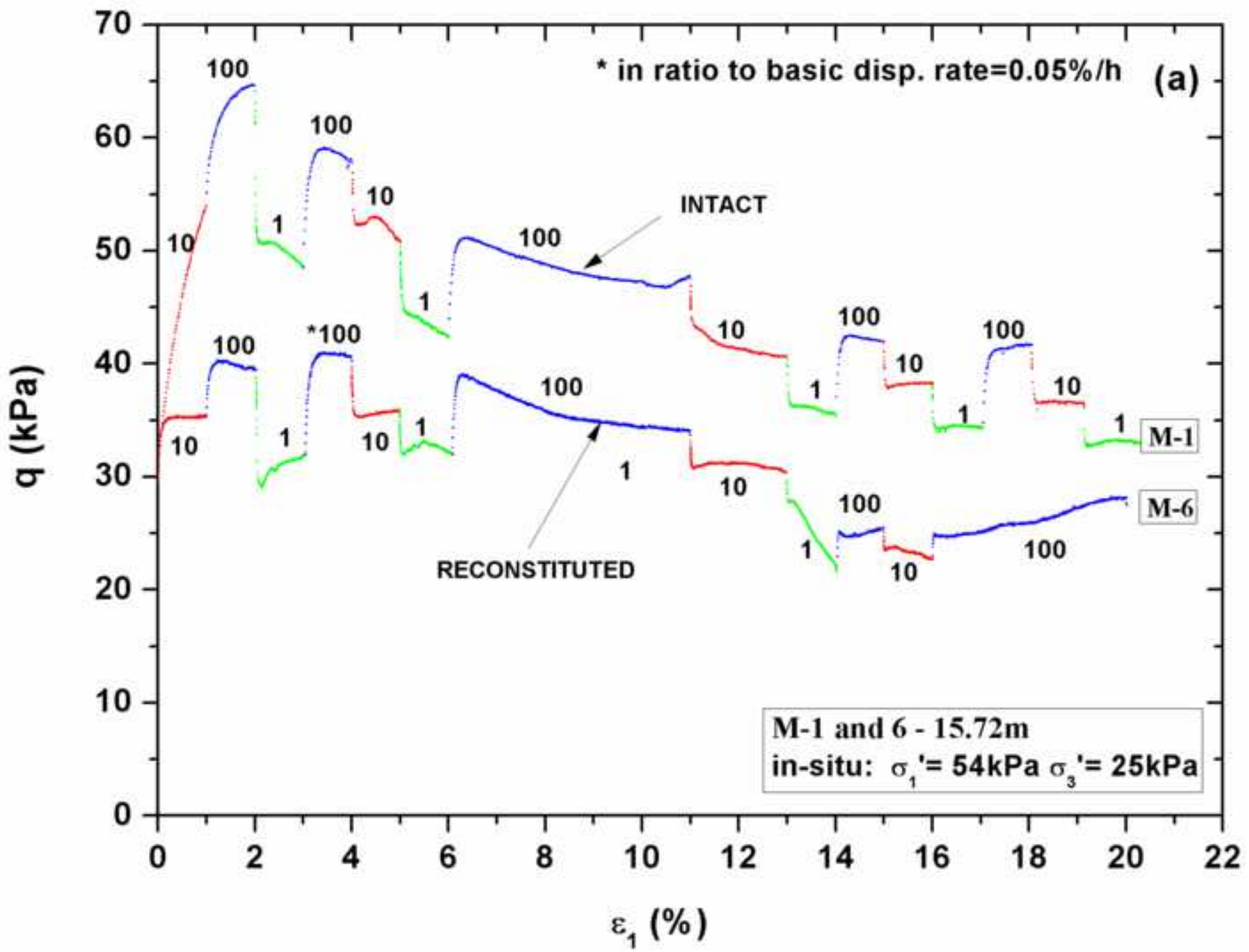




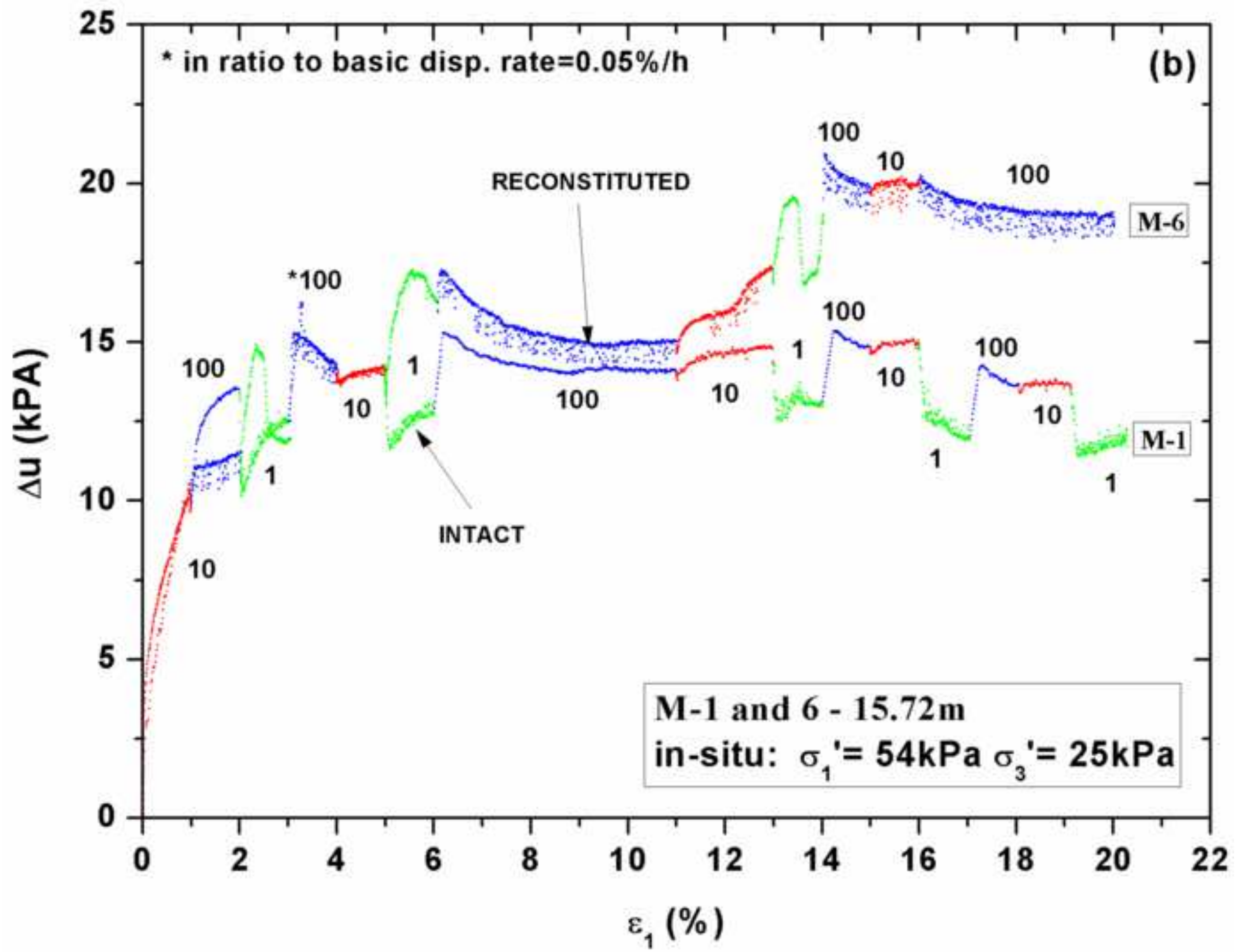




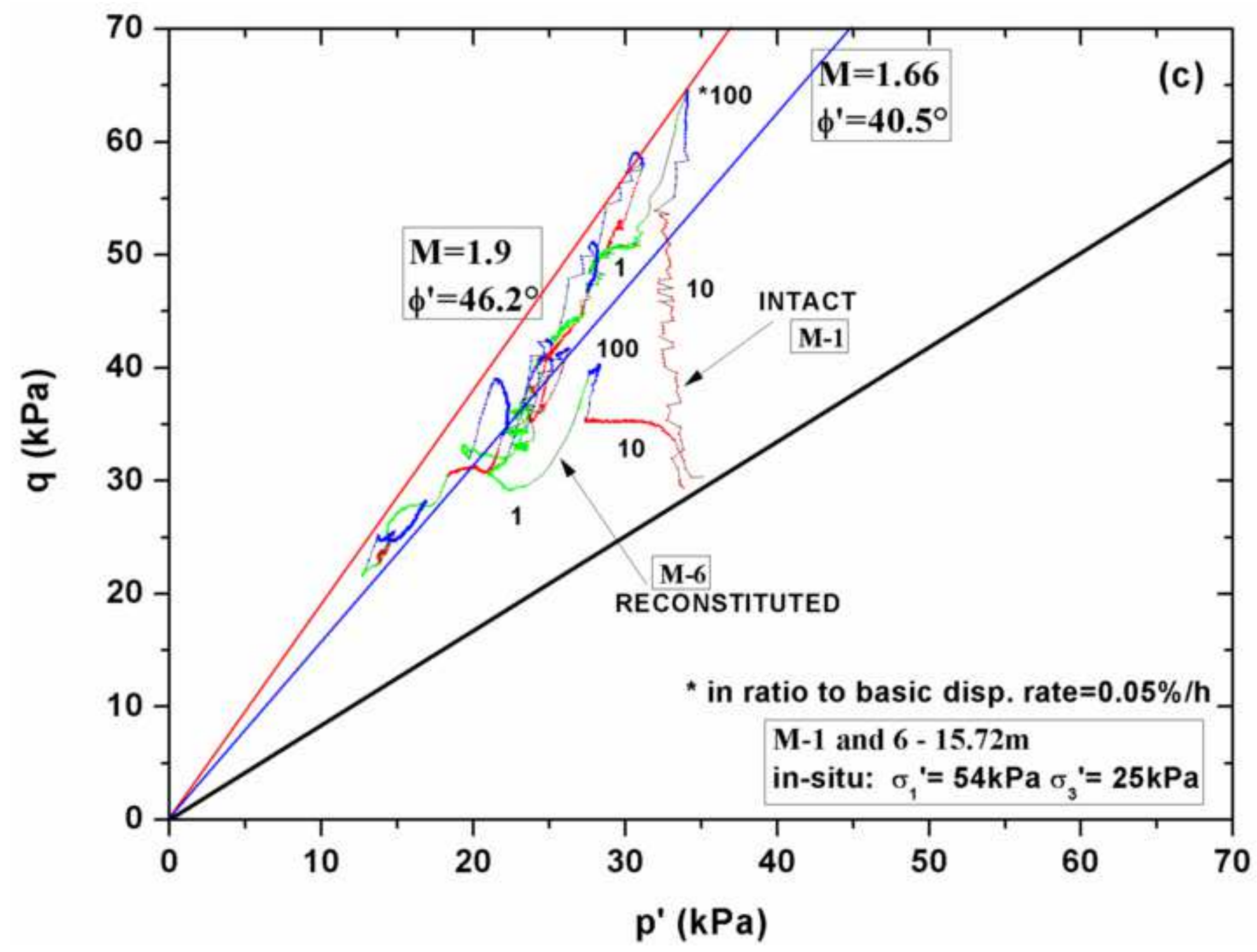



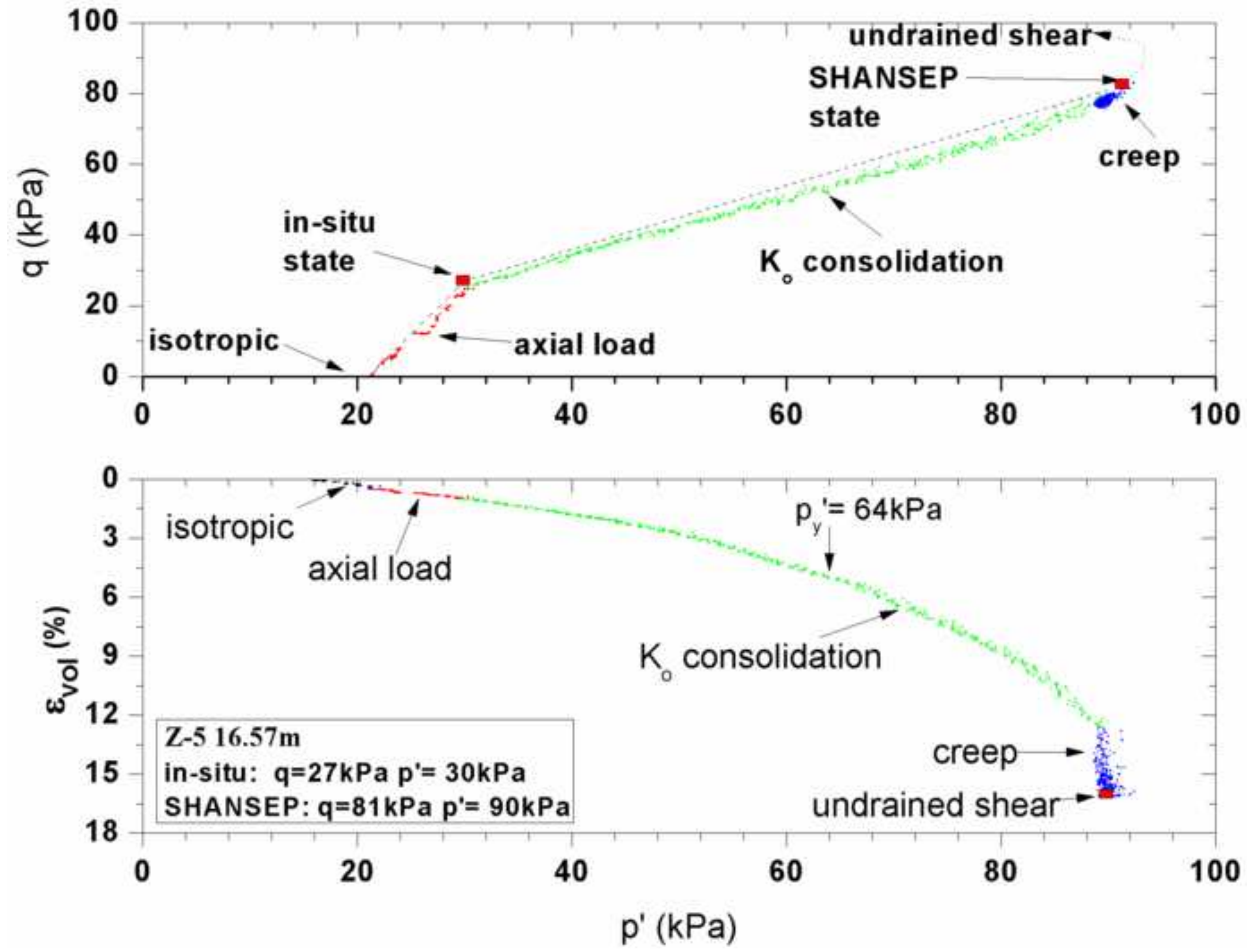

$$
p^{\prime}(\mathrm{kPa})
$$




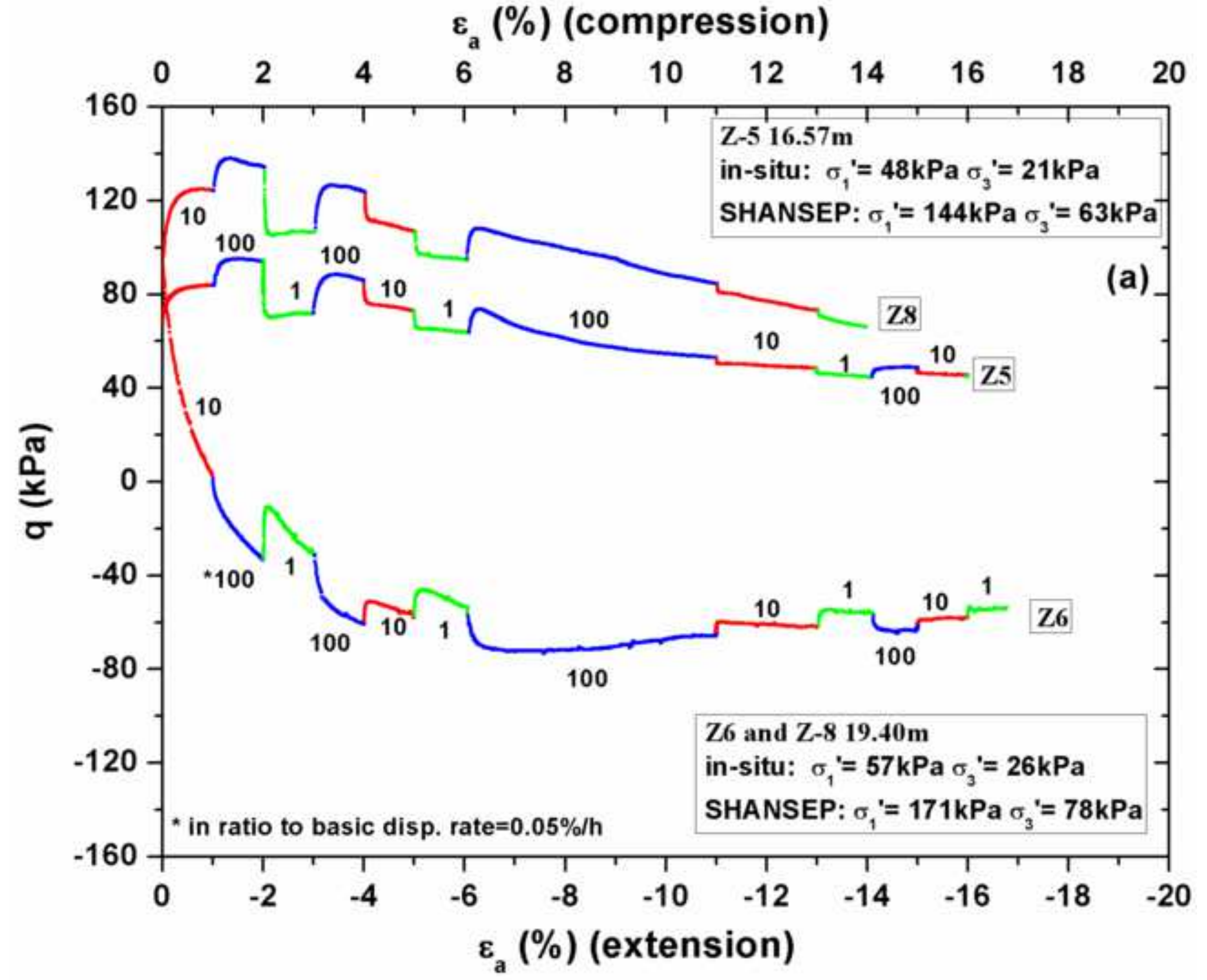




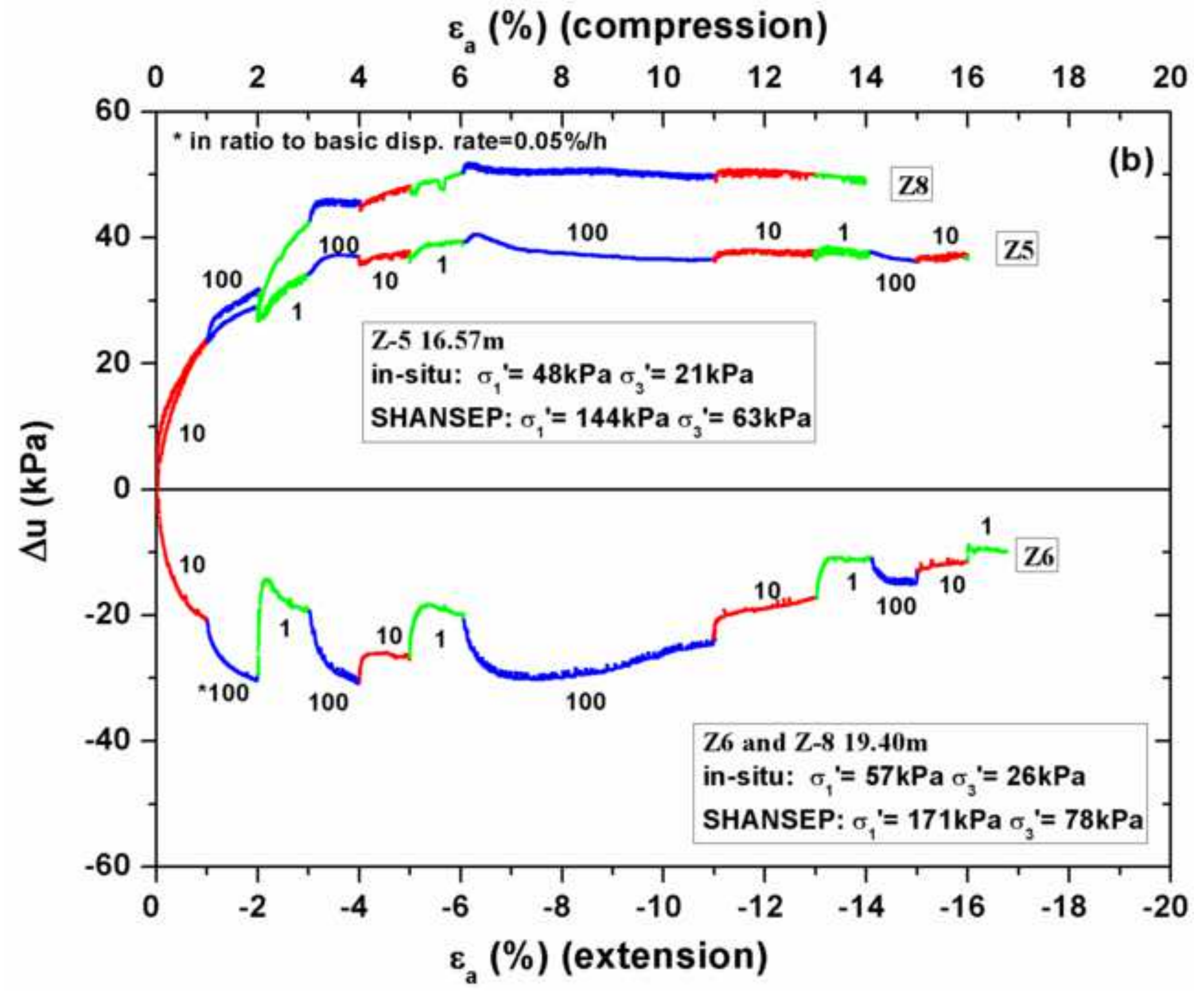




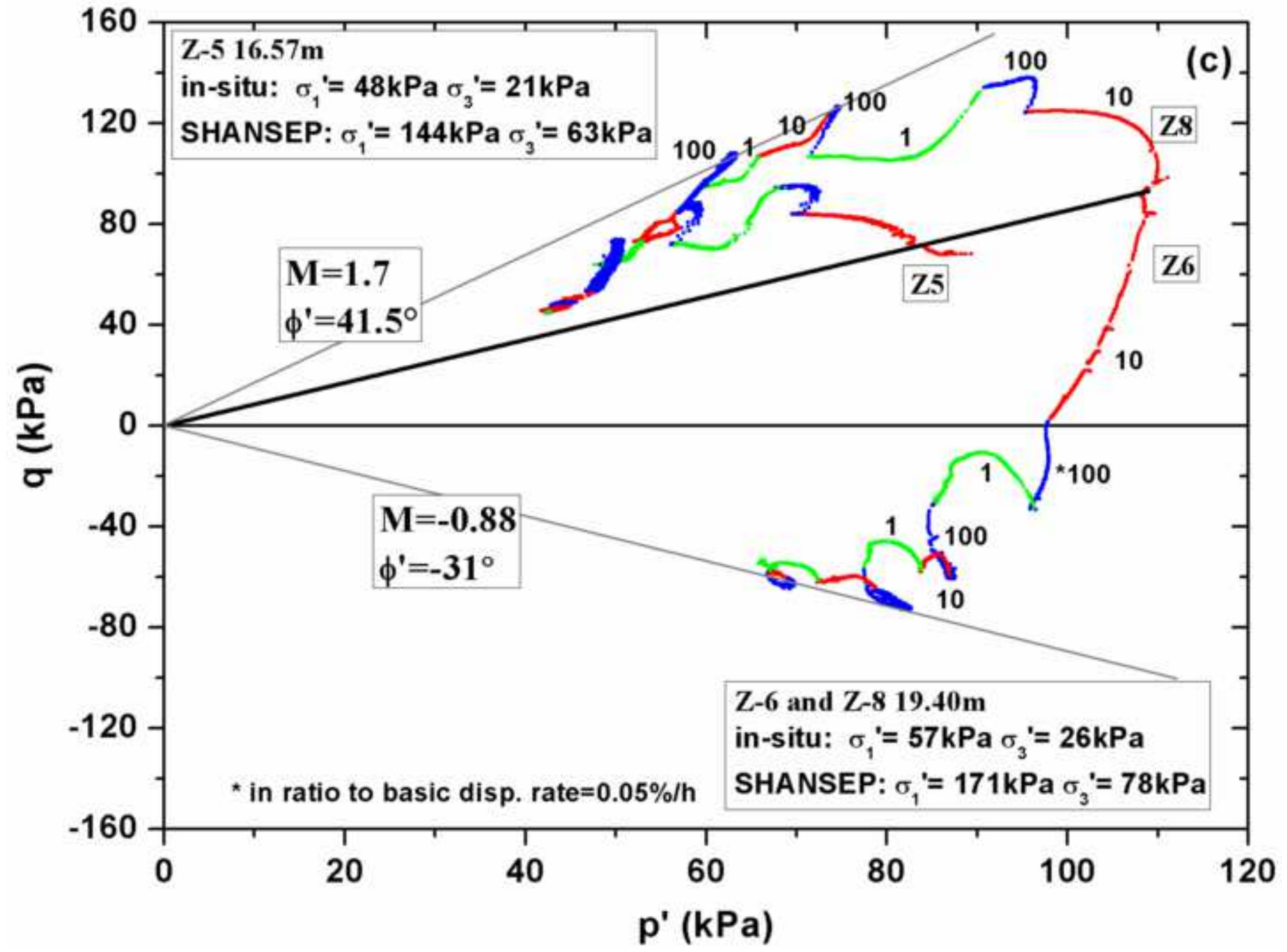

